June $2000 \quad$ - NREL/SR-550-26889

\title{
The Role of Women in Sustainable Energy Development
}

Elizabeth Cecelski

Energy, Environment \& Development Germany
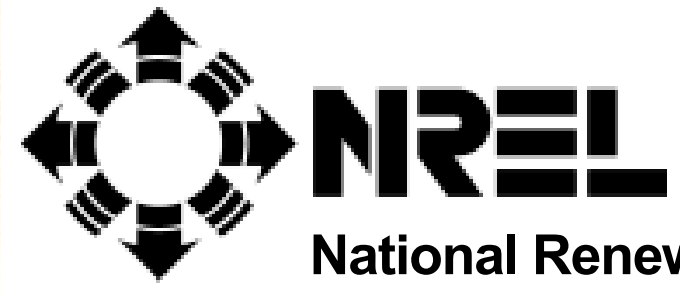

National Renewable Energy Laboratory

1617 Cole Boulevard

Golden, Colorado 80401-3393

NREL is a U.S. Department of Energy Laboratory

Operated by Midwest Research Institute $\bullet$ Battelle $\bullet$ Bechtel

Contract No. DE-AC36-99-G010337 


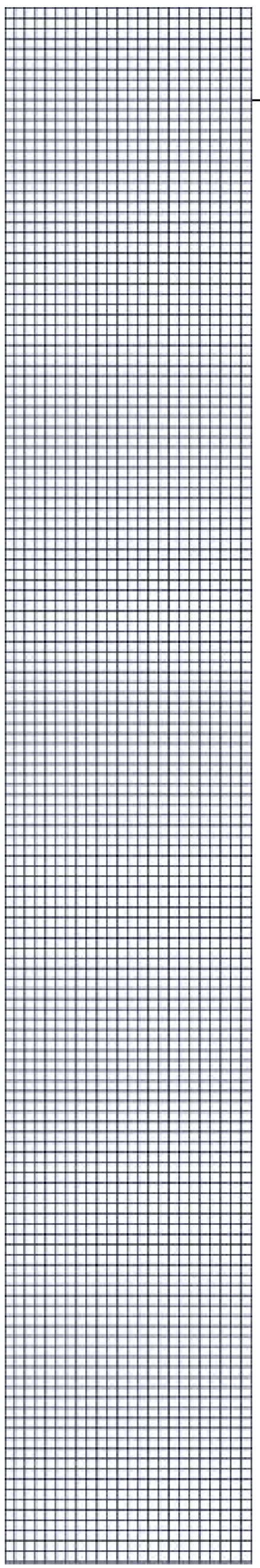

June $2000 \quad \cdot \quad$ NREL/SR-550-26889

\section{The Role of Women in Sustainable Energy Development}

Elizabeth Cecelski

Energy, Environment \& Development

Germany

NREL Technical Monitor: Barbara C. Farhar

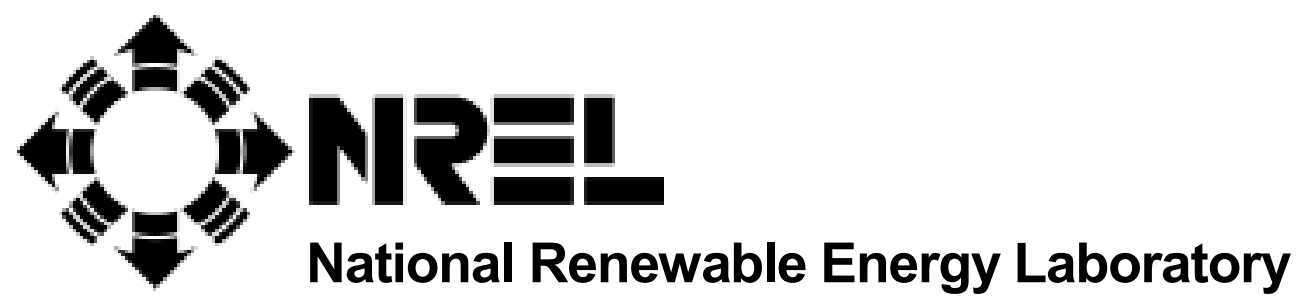

1617 Cole Boulevard

Golden, Colorado 80401-3393

NREL is a U.S. Department of Energy Laboratory

Operated by Midwest Research Institute $\bullet$ Battelle $\bullet$ Bechtel

Contract No. DE-AC36-99-G010337 


\section{NOTICE}

This report was prepared as an account of work sponsored by an agency of the United States government. Neither the United States government nor any agency thereof, nor any of their employees, makes any warranty, express or implied, or assumes any legal liability or responsibility for the accuracy, completeness, or usefulness of any information, apparatus, product, or process disclosed, or represents that its use would not infringe privately owned rights. Reference herein to any specific commercial product, process, or service by trade name, trademark, manufacturer, or otherwise does not necessarily constitute or imply its endorsement, recommendation, or favoring by the United States government or any agency thereof. The views and opinions of authors expressed herein do not necessarily state or reflect those of the United States government or any agency thereof.

Available electronically at http://www.doe.gov/bridge

Available for a processing fee to U.S. Department of Energy

and its contractors, in paper, from:

U.S. Department of Energy

Office of Scientific and Technical Information

P.O. Box 62

Oak Ridge, TN 37831-0062

phone: 865.576.8401

fax: 865.576.5728

email: reports@adonis.osti.gov

Available for sale to the public, in paper, from:

U.S. Department of Commerce

National Technical Information Service

5285 Port Royal Road

Springfield, VA 22161

phone: 800.553.6847

fax: 703.605.6900

email: orders@ntis.fedworld.gov

online ordering: http://www.ntis.gov/ordering.htm

Printed on paper containing at least $50 \%$ wastepaper, including $20 \%$ postconsumer waste 


\section{Preface}

Elizabeth Cecelski is with Energy, Environment \& Development, Breibacher Weg 104, D-51515 Kuerten (Germany), Tel. +49 2268901 200, Fax: +492268930 200, e-mail: <ececelski@t-online.de>. This paper is based partially on a paper presented at the World Renewable Energy Conference-V, 21-25 September 1998, Florence, Italy.

This study explores the question of how sustainable energy development - specifically, decentralized renewable energy technologies - can complement and benefit from the goal of increasing women's role in development. It is based on a paper originally presented at the World Renewable Energy Congress - V held in Florence, Italy, in September 1998, as a contribution to the National Renewable Energy Laboratory's (NREL's) program on gender and energy.

Many of the examples given in the paper draw on contributions to and thinking developed in connection with ENERGIA News, the newsletter of the International Network on Women and Energy. The author would like to thank both the contributors and her fellow editors (Joy Clancy, Margaret Skutsch and Saskia Everts) for making this material available and for stimulating her thinking on this subject.

The author would also like to thank Barbara C. Farhar of NREL, who managed the project, and Agnes Klingshirn of GTZ and Joy Clancy of the University of Twente, who acted as peer reviewers, for their helpful comments and suggestions. Special thanks are due to David Crawford and Stuart Smoller for editing the report, and Jane Adams and Irene Medina for word processing support. 


\section{Executive Summary}

Renewable energy will play an increasingly important role in both developing and developed countries in the future. The different implications of the wider use of renewable energy sources for women and men have hardly been examined, even though women's roles and interests in energy use and production have been well-documented. Experience in other sectors, and anecdotal evidence from the energy sector, suggest that women indeed have an important role to play in sustainable energy development. This paper, originally prepared to address the concerns of renewable energy technical experts at the World Renewable Energy Congress, reviews the literature on women's involvement in renewable energy and presents some examples of the results of including or excluding women in renewable energy development.

It addresses four questions: Why do women need renewable energy? Are women really interested in renewable energy technologies (RETs)? Will women automatically benefit from RETs? Why is a gender perspective relevant in the energy sector?

\section{Why Do Women Need Renewable Energy?}

Renewable energy development can in particular address women's needs in:

(1) The biomass cooking crisis: fuel scarcity, health and safety. Women need renewable energy to address their critical need for cooking energy. Women need cooking energy that is less labor-using, more convenient, and safer. A broad view of the entire household fuel cycle needs to be taken, including not just improved stoves but kitchen and housing design, food preparation and processing, and improved technology for the ergonomic collection and transportation of firewood. Some programs have sought to do this, but compared to other energy initiatives, household energy programs have been under-resourced and marginalized.

Furthermore, biomass-based renewable energy projects need to take into account women's dependence on biomass energy for basic needs, and the possible effects of new biomass technologies on women's access to traditional biomass resources.

(2) The human energy crisis: women's invisible time and effort. An important portion of women's economic contribution is unpaid, unrecognized and undervalued, resulting in less attention to technology development and to investment in improving women's work than men's work. Women need renewable energy to address their labor-saving and human energy needs, such as drinking water pumping, food processing and grain grinding, and transport.

(3) Energy for microenterprises: livelihoods and income. Women need renewable energy to improve profitability and safety in their energy-intensive microenterprises, and to save labor. Improved biomass-burning and other stoves and commercial-size solar cookers, solar baking ovens, solar fruit and vegetable dryers, improved fish smokers and renewable energy-powered grain grinders and millers are some of the applications that have been made to women's food-processing activities. Solar hot water heaters, refrigeration systems and photovoltaic lighting for markets, hotels and restaurants, as well as for entertainment venues are also potential uses. Lighting can also be important for allowing women to work in the evening more productively in home industries. 
(4) Energy for the modern sector: fuel substitution, efficiency and transport. Women need efficient energy in the modern sector, because women still play the key role in household energy use in modern and modernizing societies. As modern lifestyles become more rushed, women need more cooking and energy options to aid their work. Renewable energy and energy efficiency programs need to involve women because women influence their households' direct and indirect energy consumption, and educate and shape their children's future energy conservation and consumption habits. Urban transport improvements need to take women's urban transport needs - more frequent and shorter trips than men, balancing work and family, with children, safety—into account.

\section{Are Women Really Interested in Renewable Energy Technologies?}

There is a stereotype that women are not technologists and that they are not capable (even when provided with appropriate support) of building, operating and maintaining sophisticated technologies. While women do experience a number of constraints in their involvement with technology, the reality is that women's role in technology has been largely overlooked. First, women's indigenous technology innovations, often highly sophisticated, have not been considered as real "science." Evidence shows that supporting women's own innovation abilities could be a rich source of improving renewable energy technologies, while at the same time increasing women's own capacities and confidence.

Second, women are more and more adopting nontraditional work roles in the energy sector, due to the rising number of female-headed households globally, and to the increasing access by women to science and technology education. A lesson for renewable energy projects is that "male" roles are not fixed but are increasingly being undertaken by women household heads, as well as by other women. Hence, nontraditional roles for women could also be considered in renewable energy projects. The increasing numbers of professional women in the energy sector can be a source of support and role models in efforts to increase the role of women in renewable energy.

Actual experience in involving women in renewable energy activities has been fairly limited and anecdotal to date. Documentation is sparse, and more information is needed. Still, given the opportunity, women have in a number of cases demonstrated their interest by taking active roles in renewable energy projects that produce real benefits for them: that improve their quality of life, reduce their workload, or provide them with opportunities to increase their income. Women are already playing diverse roles in some renewable energy activities:

- As energy consumers and beneficiaries, women have contributed to design of household energy technologies and projects. Improved stoves programs have been more effective and produced more benefits when they have obtained women's input to product design and have targeted marketing and credit to women and men as appropriate. Some solar cooker projects are already making use of similar approaches.

- As microentrepreneurs, women have used renewable energy to increase profits and efficiency in their informal sector enterprises, and have proven themselves capable of operating and also constructing renewable energy technologies on their own, when provided with the appropriate training and support. Women may be effective renewable energy entrepreneurs, due to their experience as users of energy in households and their own enterprises; in some countries women are already marketing solar home systems successfully. 
- As extension workers and caretakers, women have been effective in operation and maintenance roles of biogas, hydroelectric and solar installations. Though some costs may be higher, due to women's need for training and their restricted mobility, others are lower, due to less staff turnover and greater reliability.

- As leaders, networkers and lobbyists, women have successfully influenced energy policy decisions at the local, national and international levels. Women do not necessarily have to build, operate or maintain renewable energy installations alone. More important is that women have a role in determining the use and benefits of the project and in managing these arrangements, and that they receive and control benefits.

\section{Will Women Automatically Benefit from Renewable Energy Technologies?}

Rural women are often assumed to be the principal beneficiaries of "improved" technologies, in particular of renewable energy technologies. Labor-saving devices are clearly a priority for rural women, given the inordinate amount of time and energy that they expend in necessary household drudgery. Two phases in rural technology initiatives can be identified that have had gender effects: those introduced to improve efficiency of production in general, and those aimed specifically at reducing women's drudgery. Unfortunately, numerous studies have shown that not only have many labor-saving technologies failed to save women's time and energy, they have sometimes even worsened women's social and economic conditions. Renewable energy development must learn from and improve on this experience.

Increasing the efficiency of energy production processes usually implies larger-scale production. Women producers, who are often part-time and small-scale, can easily be marginalized and lose control of the production process to male owners who can afford the necessary capital investment. Even technologies aimed specifically at reducing women's drudgery have often not had the desired effect, because women lack other resources needed to benefit from these technologies, such as credit, or because interventions did not take account of the realities of the cultural and economic environment.

A number of approaches have gradually been developed to solve these problems, such as surveys of women's and men's actual work activities and needs to determine appropriate interventions; participatory research using women's indigenous knowledge; and credits or subsidy schemes for purchase. Some of these have been applied successfully in energy-related interventions, notably in the household energy sector, and should receive more attention in renewable energy development.

Successful projects to assist women entrepreneurs, past experience shows, need to pay careful attention not only to technical feasibility but also to factors outside the production process, such as access to raw materials (including land ownership and control over cash crops), access to credit, social and cultural context, management and organization, leadership, and marketing. Provision of credit and assisting women's groups in other ways has been one of the most effective strategies to enable women to own and profit from these larger-scale, more efficient processing technologies.

\section{Why Is a Gender Perspective Relevant in the Energy Sector?}

The gender perspective recognizes that some issues and constraints related to project success are genderspecific, and stem from the fact that men and women play different roles, have different needs, and face different constraints on a number of different levels. Gender analysis is a methodology that seeks to understand the distinct culturally and socially defined roles and tasks that women and men assume both within the family and household system and in the community. A number of texts and training manuals 
are available on gender analysis, which has been used for many years by organizations ranging from Oxfam to the World Bank.

Why has gender analysis not been adopted more extensively in the energy sector? Not only women, but people, and socio-economic perspectives such as indigenous knowledge and people's participation, in general have been largely ignored in energy planning and policy until fairly recently. The energy sector has been defined as capital-intensive, large-scale and commercial activities; high tech requiring professional expertise; and inanimate fuels, not human energy. New trends both in energy policy and in gender analysis are now facilitating increased attention to gender analysis in the energy sector: attention to energy, environment and development relationships; gender analysis viewing women as active participants; more women in energy professions; the higher visibility of women's organizations internationally; gender training in the energy sector; and the rise of international and national networks on gender and energy.

\section{The Way Forward}

This paper shows that women are not a special interest group in renewable energy, they are the mainstream users and often producers of energy. Without their involvement, renewable energy projects risk being inappropriate, and failing. Women are the main users of household energy in developing and industrial countries; they influence or make many family purchases related to energy; they are experienced entrepreneurs in energy-related enterprises; and women's organizations are effective promoters of new technologies and active lobbyists for environmentally benign energy sources.

Renewable energy manufacturers that do not pay attention to women's needs will be missing a huge potential market. Energy policymakers who ignore women's needs will be failing to make use of a powerful force for renewable energy development. Energy researchers who leave women out of energy research and analysis will be failing to understand a large part of energy consumption and production. Donors who do not support gender-sensitive energy assistance will be overlooking one of their primary target groups.

Much work remains to be done. For example, an economic framework for including human energy and health externalities would greatly facilitate including women's activities in the energy sector. More detailed case studies of the results of including or not including women in renewable energy projects would be of enormous use in convincing policymakers and practitioners, as well as in training. The disaggregation of data by gender as standard practice in all renewable projects (gender analysis) would offer immediate practical insights to those directly involved in implementation, and also in monitoring of impacts and benefits.

A growing group of women and men, ranging from grassroots women and extensionists to researchers to policymakers and donors, believe that gender is important enough to warrant special attention in renewable energy. At the same time they know that a gender perspective represents but one piece of the complex equation that can lead to successful renewable energy projects and enterprises - not a sufficient piece alone to assure success, but a necessary piece for success. 


\section{Contents}

\section{Page}

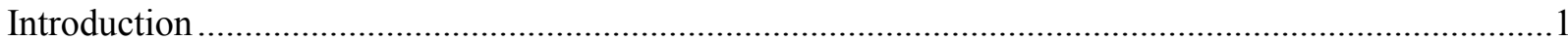

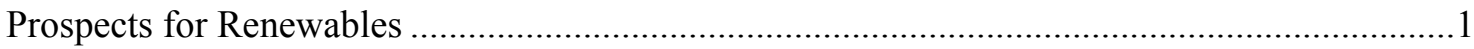

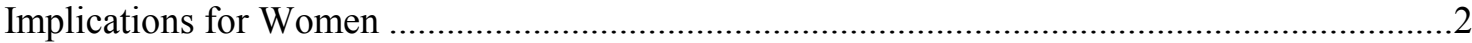

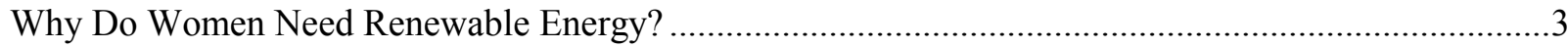

Biomass Cooking Energy Crisis: Fuel Scarcity, Health and Safety .........................................

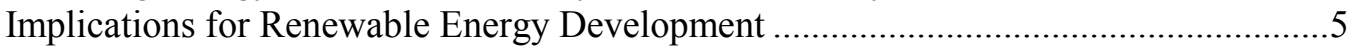

Human Energy Crisis: Women's Invisible Time and Effort.......................................................

Implications for Renewable Energy Development ....................................................

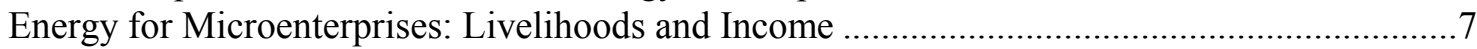

Implications for Renewable Energy Development ...............................................10

Energy for the Modern Sector: Fuel Substitution, Efficiency and Transport ............................ 10

Are Women Really Interested in Renewable Energy Technologies? ..............................................12

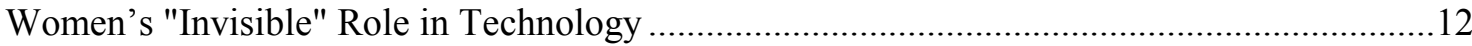

Indigenous Technical Knowledge and Women's Roles ............................................12

Nontraditional Roles by Women.........................................................................15

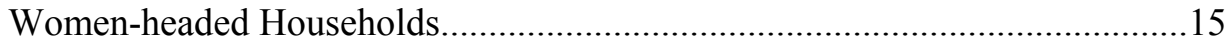

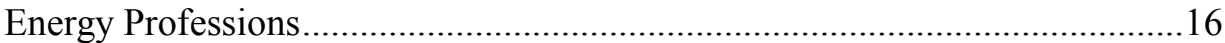

Some Experiences Involving Women in Renewable Energy Projects ...................................16

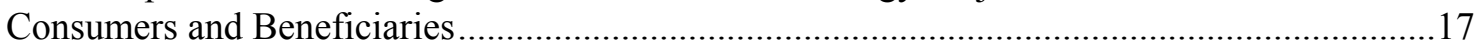

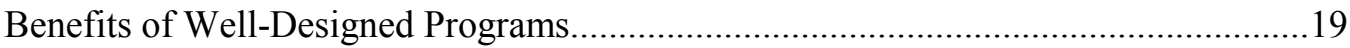

Different Perceptions of Benefits by Women and Men..............................................20

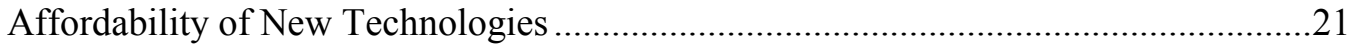

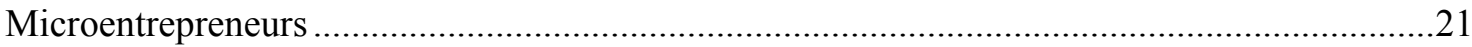

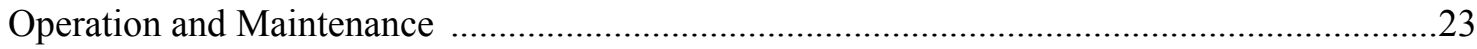

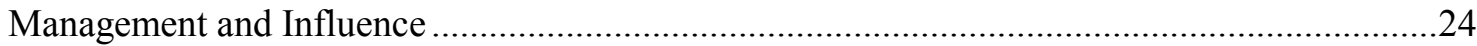

Will Women Automatically Benefit from Renewable Energy Technologies? ....................................27

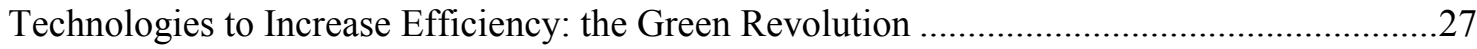

Technologies to Reduce Drudgery: "Appropriate" Technologies .............................................28

Why Is a Gender Perspective Relevant in the Energy Sector? ........................................................31

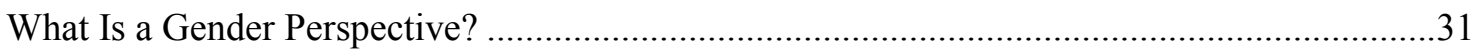

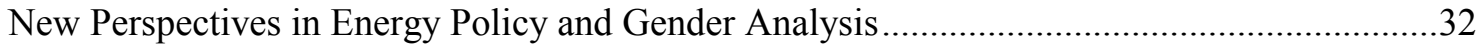

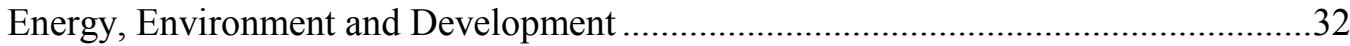

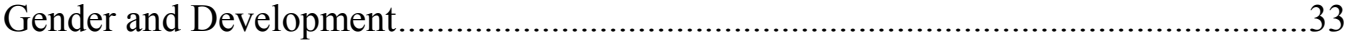

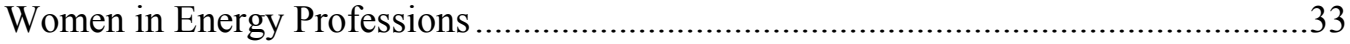

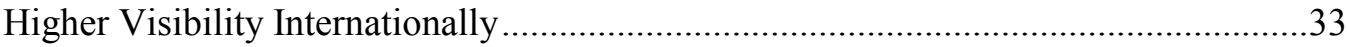

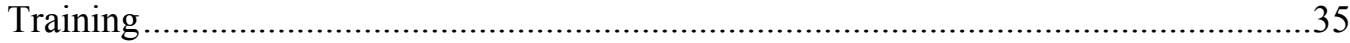




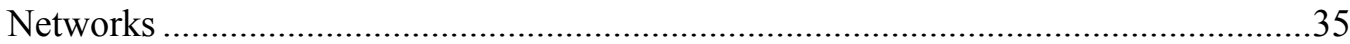

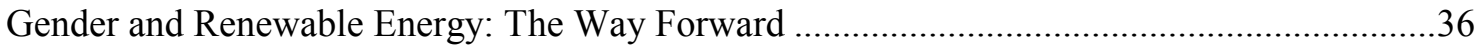

References

\section{List of Tables}

Table 2. Time Allocation to Survival Activities Among Women and Men in Four Countries............6

Table 3. Examples of Energy-intensive, Small-scale Enterprises Operated by Women .....................8

Table 4. Women-headed Households, 1990 ..................................................................................15

Table 5. Voting Results by Focus Group Participants, Six Solar Cooker Models, on

Self-Developed Criteria, Onseepkans, Northern Province, South Africa......................19

Table 6. Role of Women in NGO Biogas Programs in India, Desirable Role

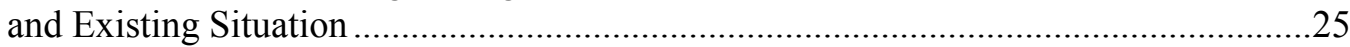

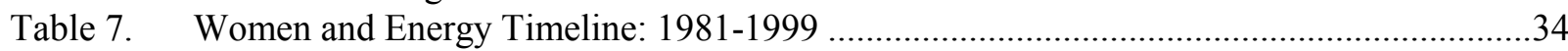

\section{List of Figures}

Figure 1. Most of Women's Work Remains Unpaid, Unrecognized and Undervalued ......................7

Figure 2. Women's Technological Innovations in the Traditional Oil Lamp, Tacna, Peru ...............14

Figure 3. Benefit Perceptions of Biogas Technology by Gender, India ...........................................20

\section{List of Boxes}

Box 1. Women's Informal Sector Work Is Part-time but Critical to Family Income .......................9

Box 2. Coping with a Lack of Electricity in a Marginal Urban Area: Women's Technology

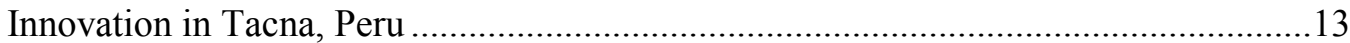

Box 3. End-User Input to Stove Design Found to be Critical ..........................................................18

Box 4. "Improved" Technologies Not Always Appropriate without Women's Traditional

Knowledge and Needs Assessment..........................................................................30

Box 5. Findings on Gender and Energy, World Renewable Energy Congress-V, 21-25

September, 1998, Florence, Italy.... 


\section{Introduction}

Renewable energy will play an increasingly important role in energy supplies in both developing and developed societies in the future. Like all energy, renewable energy production and consumption are closely linked with the goals of sustainable human development: eradicating poverty, increasing women's role in development, providing people with income-earning opportunities and livelihoods, and protecting and regenerating the environment (United Nations Development Programs [UNDP] 1997). This paper explores the question of how renewable energy development can complement and benefit from the goal of increasing women's role in development.

\section{Prospects for Renewables}

Today, both large- and small-scale renewable energy sources have an important role to play in both developing and developed societies. This role can be expected to grow as capital costs decline and hidden subsidies on competing fuel source and electricity are eliminated. Indeed, there may be many opportunities for developing countries to leapfrog the industrial countries precisely because most energy demand growth and capital investment in the future will take place in the present developing countries.

Both private- and public-sector involvement in overcoming the obstacles to wider dissemination of renewable energy sources have intensified in recent years. The establishment of dedicated institutions for renewable energy and energy efficiency finance has opened new avenues for finance and technical assistance. And concerns about climate change have led to the creation of new financing possibilities such as the Clean Development Mechanism (CDM) in the Kyoto Protocol.

Large-scale renewable energy technologies have begun to be adopted by electric utilities and some of the institutional and financial problems of integration in the grid are being solved. Some but not all of these have both large- and small-scale application potential. Bagasse-based cogeneration and sale of surplus electricity for export to the grid is under way in sugar mills in Maharashtra, India; geothermal energy serves the grid in the Philippines; and wind farms generate about 3\% of total electricity supply for utilities in Denmark and California, with rapidly falling costs likely to fuel even more rapid growth in the near future. Thermal solar plants are in operation in Europe and the United States. Hydroelectric power is a well-established renewable energy technology, already contributing a fifth of global electricity supply, though its future will be somewhat limited by environmental and social concerns (UNDP 1997).

Biomass-based technologies have been adopted (though at some cost in subsidies) on a large scale in Brazil, both the use of charcoal rather than coal in steel production, and the national fuel alcohol program replacing about half the gasoline needed for automobiles. Biomass gasification and the use of vegetable oils as fuel may also be showing up in large-scale commercial programs as well as village applications soon, as maintenance problems with producer gas engine generators are being solved.

Decentralized small-scale renewables are making considerable inroads, not limited to remote areas. Solar water heaters are by now a fairly well-established technology: in India, promotional subsidies have even been withdrawn (Doraswami 1994). Photovoltaic lighting may be the only hope for rural electrification in much of Africa, due to fiscal constraints on grid expansion: in rural Kenya, more households obtain their electricity from solar energy than from the official rural electrification program (van der Plas 1994). Village-level biogas plants still appear mainly applicable on a large scale in China and India, with a high level of community participation. Small-scale wind and hydro installations are widely used, where resources permit, for pumping water and grinding grain in remote areas, and in some cases, integrated with the grid or acting as mini/isolated grids. 
The contribution of renewables to global commercial energy is expected to increase over time from the $9 \%$ contribution (mostly hydroelectric power) made in 1990 , to $17 \%$ in $2020-2025$, and $35 \%$ in 2050 , and possibly as high as $50 \%$ by 2050 in a sustained growth or biomass-intensive scenario. Most scenarios project that renewables could contribute some 200 EJ (exajoules) per year or more by 2050 (UNDP 1997).

The issue for a number of renewable energy technologies is no longer technical reliability or economic competitiveness, which have been established in a variety of markets, but the institutional, management, and financing frameworks necessary for broader dissemination. Social and economic linkages with development issues are therefore beginning to achieve more prominence in renewable energy strategy.

\section{Implications for Women}

More than three decades ago, Boserup (1970) documented the role of women in development. Today, especially since the Beijing Conference on Women in 1995, virtually all major development organizations seek to some degree to integrate gender issues into their work, both on efficiency grounds and on the basis of social equity as a development goal in itself. ${ }^{1}$ Nonetheless, many development projects continue to be designed without consideration of their effect on women or of the role of women in their implementation. Energy and renewable energy projects are no exception. ${ }^{2}$

The different implications of the wider use of renewable energy sources for women and for men have hardly been examined. Research and project reports on renewable energy rarely include genderdisaggregated information. Just as women's activities have often been overlooked in development and energy policy generally, they could be ignored by renewable energy programs to the extent that the same supposedly "gender-indifferent" approaches and channels are involved.

In part, this state of affairs results from the masculine images conjured up in the word "energy." The reality is, in fact, often the opposite of the image. Women indeed have an important role to play in sustainable energy development. This paper, originally prepared to address concerns of renewable energy technical experts at the World Renewable Energy Congress, reviews the literature on women's involvement in energy and presents some examples of the results of including or excluding women in renewable energy development. Four questions are addressed:

- Why do women need renewable energy?

- Are women really interested in decentralized renewable energy technologies?

- Will renewable energy technologies automatically benefit women?

- Why is a gender perspective relevant in the energy sector?

\footnotetext{
${ }^{1}$ A 1997 World Bank evaluation of 185 projects, for example, found that projects with gender-related action achieved their overall objectives in relatively greater proportion than projects similar in sector and year of approval but without gender actions (Murphy 1997).

${ }^{2}$ For assessments of the extent to which gender has been included in some national and bi-lateral energy projects, see Skutsch (1995) and Hooper-Box, et al. (1998).
} 


\section{Why Do Women Need Renewable Energy?}

Women's roles and interests in energy use and production have been well-documented (Agarwal 1986; Cecelski 1992). Rural women face a crisis of biomass energy and of time and human energy, both to meet basic human needs and to earn livelihoods. Both urban and rural women must find means to meet their family and enterprise energy needs in the energy transition to more modern, commercial fuels as well. Energy efficiency and especially pricing and availability of alternative fuels continue to be a concern to women in both modernizing and developed countries, as women are primarily responsible for cooking and household management in all societies.

\section{Biomass Cooking Energy Crisis: Fuel Scarcity, Health and Safety}

Women's role in biomass cooking, the major use of energy in the household energy sector, is wellknown. More than 2 billion people globally have been estimated to depend on biomass to meet their basic energy needs (UNDP 1997). Biomass fuels comprise $80 \%$ of household fuel consumption in poor developing countries, used mainly for cooking and heating. As the major users of traditional biomass energy resources, women have practical interests and expertise about how different fuels burn, efficient fire management, fuel-saving techniques, and the advantages and disadvantages of different fuels and stoves (Intermediate Technology Development Group [ITDG] 1992; International Labour Organisation [ILO] 1987).

Rural women (and their children) are the primary collectors of wood and residue fuels for household use. They often produce biomass fuels in their own home gardens and manage and protect common lands to maximize sustainable production of a variety of forestry products (Food and Agriculture Organisation (FAO 1987). Although deforestation is generally due to market forces (such as urban and industrial fuel demands, agricultural clearing, and overgrazing), it directly affects the effort and time required for women to harvest biomass fuels.

Rough estimates of the proportion of rural women affected by fuel scarcity (based on estimates by the FAO of the percentage of household energy provided by fuel wood) are $60 \%$ in Africa, nearly $80 \%$ in Asia and nearly 40\% in Latin America and the Caribbean (UNDP 1995). Time spent in fuel collection in fuel-scarce areas can range from 1 hour to 5 hours per household per day. Other effects documented include reduced water heating and washing, and decreased time and fuel used for cooking, the whole at times even resulting in decreased female time devoted to agricultural work and food production and negative impacts on nutritional and health status (Cecelski 1987; Brouwer 1989; Kumar and Hotchkiss 1988).

Health and safety are major concerns of women in their use of biomass fuels. Smoke reduction and improved safety for children are often the two most important reasons cited by women for adopting improved stoves and fuels. In South African urban townships, the prevention of accidental kerosene poisoning of children, and the prevention of devastating housing fires caused by kerosene cooking and lighting, are important motivations given by both women and men for desiring household electrification (Mehlwana and Qase 1996; Jones, et al. 1996; Banks, et al. 1996).

The largest energy-related health impact on women and children on a global basis, however, is their high exposure to indoor air pollution in the more than half of the world's households that cook daily with wood, crop residues, and untreated coal. Typical indoor concentrations of important pollutants, such as 
Table 1. Women's Exposure to Indoor Air Pollution from Biomass Fuel Combustion

\begin{tabular}{|c|c|c|c|}
\hline & $\begin{array}{l}\text { Partic } \\
\text { conce } \\
\text { (micr } \\
\text { pollut } \\
\text { cubic }\end{array}$ & $\begin{array}{l}\text { ulate } \\
\text { ntration } \\
\text { grams of } \\
\text { ant per } \\
\text { metre of air) }\end{array}$ & $\begin{array}{l}\text { Suspended } \\
\text { particulate } \\
\text { micrograms as } \\
\text { multiple of } \mathrm{WHO} \\
\text { peak guideline }^{\mathrm{a}}\end{array}$ \\
\hline & & \multicolumn{2}{|c|}{ Kitchen area concentration levels } \\
\hline \multirow[t]{3}{*}{ Kenya, 1972} & Overnight & & \\
\hline & Highlands & $2,700-7,900$ & $12-34$ \\
\hline & Lowlands & $300-1,500$ & $2-7$ \\
\hline Kenya, 1988 & 24 hours & $1,200-1,900$ & $5-8$ \\
\hline Gambia, 1988 & 24 hours & $1,000-2,500$ & $4-11$ \\
\hline \multirow{3}{*}{ India, 1982} & Cooking with wood & 15,800 & 69 \\
\hline & Cooking with dung & 18,300 & 80 \\
\hline & Cooking with charcoal & 5,500 & 24 \\
\hline India, 1988 & Cooking & $4,000-21,000$ & $17-91$ \\
\hline Nepal, 1986 & Cooking with wood & 4,700 & 20 \\
\hline China, 1987 & All day in wood-burning kitchen & 2,600 & 11 \\
\hline \multirow[t]{4}{*}{ Papua New Guinea, 1968} & Overnight at floor level & $200-4,900$ & $1-21$ \\
\hline & Overnight at sitting level & $200-9,000$ & $1-39$ \\
\hline & \multicolumn{3}{|c|}{ Individual exposure during cooking } \\
\hline & \multicolumn{3}{|c|}{ (2-5 hours per day) } \\
\hline \multicolumn{4}{|l|}{ India: } \\
\hline \multicolumn{2}{|l|}{4 villages, 1983} & 6,800 & 30 \\
\hline \multicolumn{2}{|l|}{2 villages, $1987^{\mathrm{b}}$} & 3,600 & 16 \\
\hline \multicolumn{2}{|l|}{8 villages, $1987^{\mathrm{b}}$} & 3,700 & 16 \\
\hline 5 villages, 1988 & & 4,700 & 20 \\
\hline \multicolumn{4}{|l|}{ Nepal: } \\
\hline \multicolumn{2}{|l|}{2 villages, $1986^{\mathrm{b}}$} & 2,000 & 9 \\
\hline \multirow[t]{2}{*}{1 village, 1988} & With traditional stove & 8,200 & 36 \\
\hline & With improved stove & 3,000 & 13 \\
\hline \multicolumn{4}{|c|}{$\begin{array}{l}\text { The World Health Organization standard is } 150-230 \text { micrograms per cubic meter. The WHO peak } \\
\text { guideline recommends that a concentration of } 230 \text { micrograms per cubic meter not be surpassed more } \\
\text { than } 2 \text { percent ( } 7 \text { days) of the year. } \\
\text { b Approximately half the households used improved cooking stoves. }\end{array}$} \\
\hline
\end{tabular}

Source: Pandey (1989) cited in UNDP (1995).

respirable particulates, carbon monoxide, benzene and formaldehyde, are excessive by comparison to health-based standards. Table 1 shows some typical exposures. The largest direct impacts are on respiratory infections in children - the most significant class of disease in the world - and chronic lung disease in non-smoking women (Smith 1993). 
Physical and psychological violence against women was a major issue at the Beijing Conference on Women, and the current energy system is not exempt from these social forces. Women face violence where fuel must be collected in areas of contested access or civil disturbances, as in Sarajevo, where women faced snipers while seeking fuel supplies, or in Somalia, where the United Nations High Commission for Refugees (UNHCR) documented hundreds of cases of refugee women raped and brutalized by bandits while away from camps to collect wood fuel (The Economist 1993). There are even reports of bride suicides in India partially due to women's inability to meet their family's wood fuel needs (Agarwal 1986).

\section{Implications for Renewable Energy Development}

Thus, women need renewable energy to address their critical need for cooking energy and indeed the whole fuel cycle from production to consumption. Women need cooking energy that is less laborintensive, more convenient, and safer. A broad view of the entire household fuel cycle needs to be taken, including not just improved stoves but kitchen and housing design, food preparation and processing, and improved technology for the ergonomic collection and transportation of firewood by women. Some improved stoves programs have sought to do this; but compared to other energy initiatives, household energy programs have been marginalized and under-resourced (Peskin, et al. 1992).

Biomass-based renewable energy projects need to take into account women's dependence on biomass energy for basic needs, and the possible effects of new biomass technologies on women's access to traditional biomass resources. For example, in India some biogas plants used cow dung that previously had been available to poor landless women to use as cooking fuel, removing from them an important resource (Kelkar 1981). In Senegal, a charcoal project designed to provide fuel from state forests to urban Dakar resulted in women living in the forest area losing access to the forests for pasturing animals and gathering forest foods for home consumption (Sow 1986).

\section{Human Energy Crisis: Women's Invisible Time and Effort}

Women's long working hours in both domestic and economic activities (11 hours to 14 hours per day) have been documented in nearly every country. Of the total burden of work, women carry on average $53 \%$ in developing countries and 51\% in industrial countries (United Nations (UN) 1995).

Compared to men, women in rural areas of developing countries spend long hours working in survival activities such as firewood collection, water hauling, food processing, and cooking (Table 2). Women's energy and time scarcity impinges on the provision of these basic services. The proportion of rural women affected by water scarcity, for example, is estimated at $55 \%$ in Africa, $32 \%$ in Asia, and $45 \%$ in Latin America, with the median time for collecting water in the dry season at 1.6 hours per day (UN 1995).

Human energy is essential to survival in the rural production system. Much of this human energy is unpaid family labor provided by women. Because it is unpaid, it does not enter the market system. Because it is metabolic energy and difficult to measure, it does not enter the conventional energy system, which consists in this view of oil, natural gas, coal, hydropower, nuclear, wind, solar, biogas, and geothermal energy and does not account for the muscle power provided by human beings and animals performing the same tasks. Because they work longer hours than men and a larger proportion of their 
Table 2. Time Allocation to Survival Activities Among Women and Men (Hours per Day)

\begin{tabular}{|c|c|c|c|c|}
\hline Activity & Indonesia & $\begin{array}{l}\text { Burkina } \\
\text { Faso }\end{array}$ & India & Nepal \\
\hline \multicolumn{5}{|c|}{ Firewood collection } \\
\hline Women & 0.09 & 0.10 & 0.65 & $2.37^{\mathrm{a}}$ \\
\hline Men & 0.21 & 0.03 & 0.57 & $0.83^{\mathrm{a}}$ \\
\hline \multicolumn{5}{|l|}{ Water hauling } \\
\hline Women & 0 & 0.63 & 1.23 & 0.67 \\
\hline Men & 0 & 0 & 0.04 & 0.07 \\
\hline \multicolumn{5}{|l|}{ Food processing } \\
\hline Women & $2.72^{b}$ & 2.02 & 1.42 & 0.70 \\
\hline Men & $0.10^{\mathrm{b}}$ & 0.17 & 0.27 & 0.20 \\
\hline \multicolumn{5}{|l|}{ Cooking } \\
\hline Women & - & 2.35 & 3.65 & 2.10 \\
\hline Men & - & 0.01 & 0.03 & 0.38 \\
\hline \multicolumn{5}{|c|}{ Average total work time } \\
\hline Women & 11.02 & 9.08 & 9.07 & 11.88 \\
\hline Men & 8.07 & 7.05 & 5.07 & 6.53 \\
\hline
\end{tabular}

Source: Constructed by the author using data from Tinker (1990) and Hotchkiss (1988) in Cecelski (1995).

work falls outside the market, women are not credited for their true contributions when metabolic energy is excluded from energy analysis.

Women's time spent on these survival tasks is largely invisible in current methods of reporting energy patterns and statistics. For example, while the energy used by an electric pump that transports drinking water can be easily measured and reported, the human energy expended by a woman carrying water goes unmeasured, unmonetized, and unrecorded in energy statistics. Although the energy expended for a water-mill grinding grain is accounted for in industrial energy balances, the calorific efforts of women doing the same task with mortar and pestle are not. Trucks transporting crops consume fossil fuels that are traded and valued through market mechanisms; the energy of women headloading the same maize to market in baskets is excluded from quantified energy balances.

Because such non-monetized "human energy" services are not included in national energy accounts, a misleading picture of the real economic importance of informal production is given, under-representing women's muscle as an energy source. This omission in the statistical accounts tends to support an investment bias towards large-scale energy infrastructure projects. 
Figure 1 shows graphically how national accounts undervalue women's economic contribution. About half of the total work time of both men and women is spent in economic activities in the market or in the subsistence sector. The other half normally is devoted to unpaid household or community activities. In industrialized countries, men's total work time is spent roughly two-thirds on paid activities and onethird on unpaid activities. For women, the situation is reversed. In developing countries, more than three-quarters of men's work is in market activities. As a result, men receive a much larger share of cash income and recognition for their economic contributions. Conversely, most of women's work remains unpaid in non-marketed or subsistence activities and is thus unrecognized and undervalued. If unpaid activities were treated as market transactions at prevailing wages, global output would increase by US\$16 trillion, of which US\$11 trillion would correspond to the nonmonetized, "invisible" contribution of women (UNDP 1995).

The figure dramatically captures the undervaluation of women's economic contribution:

- Of the total burden of work, women carry more than half.

- Three-fourths of men's work is in paid market activities, compared with only one-third of women's work.

- As a result, men receive the lion's share of income and recognition for their economic contribution -while most of women's work remains unpaid, unrecognized and undervalued.

Figure 1. Most of Women's Work Remains Unpaid, Unrecognized, and Undervalued

Source: UNDP (1995).

\section{Implications for Renewable Energy Development}

An important portion of women's economic contribution to development is unpaid, unrecognized and undervalued, resulting in less attention to technology development and to investment in improving women's work than men's work. Women need renewable energy to address their labor-saving and human energy needs, such as pumping water for household uses, food processing and grain grinding, and transport. For example, new energy technologies for agricultural irrigation and pumping and their large infrastructures are primarily within the domain of men. These have received far more energy policy attention than technologies for pumping and transporting drinking water, which falls almost exclusively within the domain of women's work in the informal sector.

Similarly, ways to improve pedestrian and public transport, used more by women, have received far less attention in transport energy policy than have alternative liquid fuels for automobiles, used and owned more by men in most countries. Currently, enormous attention is being directed at photovoltaic household electrification, used for lighting and media, while women's critical need for improved cooking with electricity or other sources is under-researched and under-financed.

\section{Energy for Microenterprises: Livelihoods and Income}

Both rural and urban women need adequate energy supplies for their small- and medium-scale enterprises and home industries. Many of these informal sector activities are highly fuel-intensive, and their viability and costs are affected by energy prices and availabilities. Examples of energy-intensive microenterprises usually operated by women include food-processing industries and kiln-using 
manufacturing activities. Their enterprises also encompass numerous service-sector activities (Table 3 ). Because fuel is a significant cost factor, there is a commercial motivation to improve the efficiency of the entire process.

Table 3. Examples of Energy-intensive Small-scale Enterprises Operated by Women

\begin{tabular}{|c|c|}
\hline Enterprise & Comments \\
\hline Beer brewing & $\begin{array}{l}25 \% \text { of fuelwood used in Ouagadougou; main source of income } \\
\text { for } 54 \% \text { of women in surveyed Tanzanian village; } 1 \mathrm{~kg} \\
\text { wood/litre beer }\end{array}$ \\
\hline Rice parboiling & $15 \%-20 \%$ of firewood in some districts of Bangladesh \\
\hline Tortilla making & $1 \mathrm{~kg}$ wood $/ 0.4 \mathrm{~kg}$ tortillas \\
\hline Bakeries & $\begin{array}{l}\text { Wood is } 25 \% \text { of bread production costs in Kenya; } 30 \% \text { in Peru } \\
0.8-1.5 \mathrm{~kg} \mathrm{wood} / 1 \mathrm{~kg} \text { bread }\end{array}$ \\
\hline Shea butter production & $60 \%$ of cash income for women in parts of Sahel \\
\hline Fish smoking & $\begin{array}{l}40,000 \text { tons wood } / \text { year in Mopti, Mali; } 1.5-12 \mathrm{~kg} \text { wood } / \mathrm{kg} \\
\text { smoked fish; fuel is } 40 \% \text { of processing costs }\end{array}$ \\
\hline Palm oil processing & $\begin{array}{l}\text { Extremely arduous, requiring lifting and moving heavy } \\
\text { containers of liquid; } 0.43 \mathrm{~kg} \text { wood/1 litre oil; } 55 \% \text { of income } \\
\text { of female-headed households in Cameroons study }\end{array}$ \\
\hline Gari (cassava) processing & $\begin{array}{l}\text { Women in } 2 \text { Nigerian districts earned } \$ 17 / \text { year each; } 1 \mathrm{~kg} \\
\text { wood } / 4 \mathrm{~kg} \text { gari }\end{array}$ \\
\hline $\begin{array}{l}\text { Hotels, restaurants, guest houses, } \\
\text { tea shops }\end{array}$ & $816,865 \mathrm{Mt}$ (million tonnes) wood annually in Nepal \\
\hline Food preparation and processing & $\begin{array}{l}13 \% \text { of total household income in Nepal; } 48 \% \text { of mothers in } \\
\text { Dangbe district in Ghana engaged; } 49 \% \text { of women in one village } \\
\text { in Burkina Faso }\end{array}$ \\
\hline Pottery making & $\begin{array}{l}\text { Men and women both have distinctive roles in different } \\
\text { processes }\end{array}$ \\
\hline Soap-making costs in Bangladesh & Fuel is high percentage of production \\
\hline
\end{tabular}

Source: Biomass Energy Services and Technology (BEST) (1988); Gordon (1986) cited in Cecelski (1995). 
Like women's unpaid labor in the household production system, women's informal sector enterprises are often invisible in energy accounts. Yet the energy consumed by these industries, not only in human labor but in fuel, is not insignificant. On average, small industries probably use $10 \%$ to $50 \%$ of total wood consumption in rural areas and in biomass-using urban areas, as well (BEST 1988). (BEST is in table source above.)

Box 1

Women's informal sector work is part-time but critical to family income.

Women often participate in energy-intensive microenterprises on a seasonal or part-time basis and as an extension of their households. But women's work in these industries is nonetheless a critical source of income to their households. In one village surveyed in Tanzania, beer-brewing was the main source of income for $75 \%$ of the women, followed by salt-making and firewood selling - all energy-related activities (Hannah-Andersson 1984). Many of the products are produced for local markets and contribute to meeting local nutritional needs. In the Sahel, shea nut butter processing makes up $60 \%$ of cash income of women and provides an important source of fats to the community.

Women from poor and landless households are most dependent on informal-sector employment, especially during economic crises and during slack periods in the farming cycle when cash is in short supply. An International Labour Organisation (ILO) study in Peru found that women's numerous smallscale activities became critical to household survival during economic recession, when women were better able than men to adjust flexibly to unemployment and market demand (Alcantara 1986). Similarly, during Ghana's structural adjustment and high male unemployment in the mid-1980s, the only cash income available to some households near Accra was from women's small-scale charcoal making (Ardayfio 1986).

Many biomass- and energy-based small industries have been severely affected by rising energy costs, fuel shortages, and deforestation. In the industries mentioned above, energy is a significant cost factor. Woodfuel is estimated to account for $25 \%$ of production costs of dolo beer in Burkina Faso, $30 \%$ of bread baking costs in Kenya and Peru, and about $20-25 \%$ of food processing production costs generally (BEST 1988). Food processing was identified in an urban energy study in Dar es Salaam, Tanzania, as the least efficient energy user in the urban informal sector (Hosier 1994). Although some producers are able to substitute more efficient modern fuels, there is evidence that fuel wood scarcities and rising costs pose a constraint on production.

These industries tend to be low-wage, labor- and effort-intensive, and tiring, as well as sometimes dangerous to women's health. As many as 106 hours are required to process $30 \mathrm{~kg}$ of shea nuts. The production of kenkey (maize balls) can take up to six days, involving soaking, milling, fermentation, dough making, cooking, ball making and boiling. The production of palm and other oils is extremely arduous, requiring lifting and moving heavy containers of hot liquid. Women in industries that use biomass energy are exposed to even more burns and smoke than the well-documented exposures of women using biomass as domestic fuel. Smoke and other harmful emissions are often present in large quantities. And operators are often dangerously exposed to furnace heat and steam for long periods (BEST 1988). 


\section{Implications for Renewable Energy Development}

Women need renewable energy to improve profitability and safety in their energy-intensive microenterprises and to save labor. Improved biomass-burning and other stoves and commercial-size solar cookers, solar baking ovens, solar fruit and vegetable dryers, improved fish smokers and renewable energy-powered grain grinders and millers are some of the applications that have been made to women's food-processing activities. Solar water heaters, refrigeration systems, and photovoltaic lighting for markets, hotels, and restaurants, as well as for entertainment venues, are also potential uses. Lighting can also be important for allowing women to work in the evening more productively in home industries.

Successful projects to assist women entrepreneurs, past experience shows, have had to pay careful attention not only to technical feasibility but also to factors outside the production process. These include access to raw materials, including land ownership and control over cash crops, credit, social and cultural context, management and organization, leadership, and marketing. Provision of credit and assisting women's groups in other ways has been one of the most effective strategies to enable women to own and profit from these larger-scale, more efficient processing technologies.

\section{Energy for the Modern Sector: Fuel Substitution, Efficiency, and Transport}

While women's role in traditional biomass cooking has been widely acknowledged, there has been a tendency to believe that women's role in energy use ends with the transition to modern, commercial energy such as kerosene, gas, and electricity, or renewable sources.

On the contrary, women still need efficient energy, because women still play the key role in household energy use in modern and modernizing societies. Women are still responsible for cooking with modern fuels, and they make critical decisions about fuel substitution and the purchase of stoves and other appliances, based on their fuel preferences and budget constraints. As modern lifestyles become more rushed, women need more cooking and energy options to aid their work. These choices are of course relevant to programs that improve energy efficiency.

Perhaps even more important, renewable energy and energy efficiency programs need to involve women because women influence their households' direct and indirect energy consumption, and educate and shape their children's future energy conservation and consumption habits. Women decide on or influence:

- The use of lighting, heating and air conditioning, hot water and electrical appliances, including the choice of time of use, and, therefore, peak use.

- Household purchases of goods and services, which may be more or less energy-intensive or "wasteful", e.g., packaging.

- Household management habits, such as recycling and composting.

- The use of household transport and choices about the use of private automobiles, bicycles, or public transport.

Women walk and take public transport more frequently than men. In many countries, there are large differences between men and women in automobile ownership and access as well as in possession of driver's licenses. Women tend to make a number of shorter and more complex daily trips for shopping, 
schools, part-time employment, and volunteer work. Current urban transport systems are not only energy-intensive, but can often restrict the mobility of those who do not use them (e.g., pedestrians, cyclists, and users of public transport) (Spitzner 1993; Sloman 1993). Cultural limitations on women's use of transportation may reinforce these restrictions. One energy efficiency effort that has sought to address women's urban transport needs is the mini-van taxi program of the Mid-Rand Transport Association in South Africa. Private mini-van taxis provide the main source of cheap, rapid public transport in urban areas in South Africa, but are plagued with problems of safety, inadequate service, and violence related to competing lines. These problems especially affect women, who, when traveling with children or moving around each day to a different work site, must change taxis numerous times or take long detours to avoid violence. With assistance from the Ministry of Energy and the International Institute for Energy Efficiency (IIEE), the Association has been addressing these problems; a woman currently heads the program. She cites women's negotiating skills as a major factor in its success in providing a safer and more energy-efficient public transport system (Wonfor 1998).

Reducing women's drudgery is a frequently cited objective of rural electrification, and women have sometimes been cited as the prime beneficiaries of rural electrification, since they spend more time in the home and hence may use improved lighting and other appliances more. Electric irons, for example, are widely enjoyed for their cleanliness, safety and ease of use. Health benefits from replacing kerosene lighting and coal- or biomass-fired cooking with a cleaner electric source should also be considered. Much is known about the very serious health effects of cooking with biomass fuels. But in the case of rural electrification, a more important interest would be in the health effects of kerosene fumes from lamps, since this is the main replacement effect. Safety of kerosene lamps and charcoal-fueled ironing, and of storing kerosene, especially for children, is another consideration.

Cooking with electricity has received attention in micro-hydro development in China and Nepal, and electric cooking has been spontaneously adopted by rural as well as urban women in a number of Asian countries (electric rice cookers) and in South Africa, despite its inefficienicies and costs. Development of low-cost and low-wattage electric cookers would make this time-saving option more accessible.

Electrification could benefit women in other areas (Cecelski 1996). Electrification of rice mills and other grain and food processing facilities - the most common rural industries to electrify - may also reduce women's workload in the home. Additional income opportunities from home-based industry work in the evenings with improved lighting could also benefit women and children. Electrification of community water supplies, schools and health clinics, as well as better security from street lighting and improved lighting for reading at home could benefit women and children disproportionately. But these benefits depend on coordination of the provision of this infrastructure with electrification and its maintenance.

In general, however, it must be said that we know relatively little concretely about the impacts of rural electrification on women and children. Case studies and monitoring and evaluation of social and economic benefits are very much needed.

Communications is another area where women-who tend to be less mobile and more isolated than men - could benefit from, e.g., photovoltaic-operated telephone stations to reduce their isolation. 


\section{Are Women Really Interested in Renewable Energy Technologies?}

Are rural women really interested in renewable energy technologies-aren't they culturally unprepared to work on energy projects? And what do men think about this type of approach? Aren't women tied down with household chores and children, so they are difficult to reach? Are women able to organize themselves to participate in renewable energy projects or to influence policy? Is there really any link between women's use of energy in developing countries, and the commercialization of renewable energy technologies? These are some of the doubts expressed by renewable energy technologists about involving women in renewable energy.

Women's role in technology has often been "invisible," like women's work. Yet women's roles in developing indigenous technical knowledge is now well-documented. Supporting women's own innovation abilities could be a rich source of improving renewable energy technologies, while at the same time increasing women's own capacities and confidence.

Women are also increasingly playing nontraditional roles in energy technology development and use, both because more women are de facto heads of households, and due to the increasing presence of women in energy professions.

Experience in involving women in renewable energy activities has been fairly limited and anecdotal to date. Still, given the opportunity, women have in a number of cases demonstrated their interest by taking active roles in renewable energy projects that produce real benefits for them: that improve their quality of life, reduce their workload, or provide them with the chance to increase their income. Women are already playing diverse roles in some renewable energy activities as energy consumers and beneficiaries; as microentrepreneurs; as extension workers and caretakers; and as leaders, networkers and lobbyists.

\section{Women's "Invisible" Role in Technology}

A stereotype holds that women are not technologists and that they are not capable (even when provided with appropriate support) of building, operating, and maintaining sophisticated technologies. While women do experience a number of constraints in their involvement with technology, the reality is that women's role in technology has been largely overlooked. First, women's indigenous technology innovations, often highly sophisticated, have not been considered as real science. Second, women are adopting nontraditional work roles, due to the rising number of female-headed households globally, and to their increasing access to science and technology education.

\section{Indigenous Technical Knowledge and Women's Roles}

Women's indigenous technical knowledge and innovative solutions to problems are in evidence in a wide range of activities (Appleton 1995b). "Specific spheres of activity become the domains of different genders as they increase their knowledge and skill over time. As a result, local knowledge and skills held by women differ from those held by men" (Appleton, et al. 1995a). The problem is the low status accorded to women's technical knowledge, and the assumption that it is inferior and non-scientific.

For example, in Afghan refugee camps in Pakistan in the mid-1980s, male stove designers - unable to enter Afghan homes due to purdah constraints - pointed to the crude circular mud stoves built outside in the compounds as evidence of the need for improved metal stoves - the stoves were already being produced by men - to be produced (by men) in a central workshop. On entering the homes, however, a female expert found that the women themselves had built sophisticated mud stoves with several potholes, 
metal chimneys, and vents to adjust draft. The women cited the difficulty of gathering the right kind of clay for the stoves and of obtaining metal tins for chimney and draft construction as the principal obstacles to improving their own stoves (Cecelski 1983).

It is often only the failure of so-called improved technology projects that leads scientists to investigate and acknowledge traditional technologies. For example, in the 1970s, women's expertise in building traditional stoves in West Africa finally had to be acknowledged by stove engineers, when their own "improved" models failed to achieve efficiencies in field use as high as those of traditional models.

Box 2

Coping with a Lack of Electricity in a Marginal Urban Area: Women's Technology Innovation in Tacna, Peru

A women's group in a marginalized urban area of Tacna, Peru, wanted electricity in their homes to make the most of the evening to speed up their textile work; to feel secure in their homes; to facilitate caring for their children; to make the night less dark; and to light the streets that they and their families used.

With no prospect of electrification in sight, the women decided to cope by improving the mecha chua, a traditional handmade candle that is smelly and smoky but gives light for a couple of hours at least. The women added mechanisms for faster lighting; making the kerosene fumes safer; making better wicks; making it more stable on the wall; saving fuel by using water; preventing accidents from happening when the lamp is on; and even making it more artistic and attractive by means of colorful decoration (see Figure 2).

Lamps manufactured this way from waste materials and with tools found in the home are very cheap. The women work on a kind of production line in the oil-lamp workshop, because some of them are more skillful at preparing the materials, others at cutting, others at assembling, and others at finishing off. Fuel consumption of the lamp is minimal. It can be lit all night and lasts approximately two nights, a total of about eight hours .... The lamps are easy to maintain, requiring only cleaning after use ... . It extinguishes itself when the fuel is finished. To keep it is out of the reach of children, it can be hung on the wall by its handles.

The women consider the lamp to be a marketable product, particularly when the areas of Tacna that do have electricity endure six-month periods of power restrictions between June and November every year. Its use may be extended to other marginal settlements of the city . . . Further, the women realize their self esteem, and the experience has opened new options for the women to develop their own solutions to their day-to-day problems.

Adapted from Yturregui (1998). 


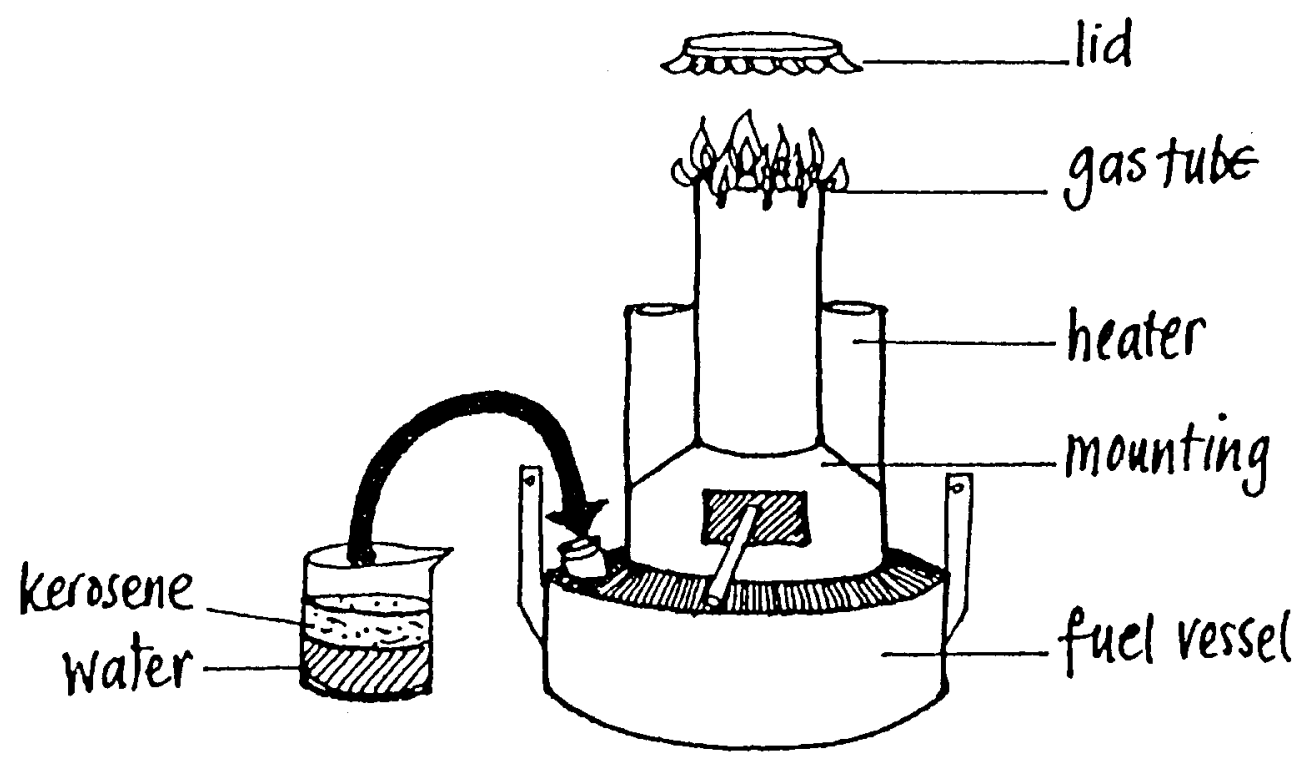

Figure 2. Women's Technological Innovation in the Traditional mecha chua Oil Lamp, Tacna, Peru ${ }^{3}$

Source: Yturregui (1998)

A number of case studies which illustrate the wealth of women's local technical knowledge and skills in food production and processing have been documented by the United Nations Development Fund for Women (UNIFEM) (Ilkaracan and Appleton 1994). In Sudan, women use complex processes in the fermentation of food products, and techniques for water purification that parallel those of water treatment plants. Fruit preservation and asmi (sweet) production in Sri Lanka, cassava processing in Uganda, salt extraction in Sierra Leone, pottery-making in Kenya, and daddawa (soybean) processing in Nigeria are all examples of sophisticated energy-using food technologies developed and used by rural women. The case studies indicate clearly that women are not merely passive owners of knowledge, but adapt and improve their traditional techniques in response to changing conditions.

Other cases illustrate how women can play an indirect yet important role in the development of equipment and techniques, in collaboration with development practitioners or local artisans. In Ghana, for example, technologists listened to, worked together with, and built on the knowledge of women in developing a less time- and labor-consuming technology for processing shea butter. The main difficulty was to come up with a method that could approach the high quality and the high rate of extraction $(83 \%$, which compared favorably with industrial technology) of the traditional methods developed by the women (Ilkaracan and Appleton 1994).

Hence, supporting women's own innovation abilities could be a rich source of improving renewable energy technologies, while at the same time increasing women's own capacities and confidence.

\footnotetext{
${ }^{3}$ The kerosene floats on the water within the fuel vessel and the lamp burns for up to eight hours before the wick reaches the water and extinguishes the flame.
} 


\section{Nontraditional Roles by Women}

Women are also increasingly assuming nontraditional roles in energy because more women are de facto heads of households, and because of the increasing presence of women in energy professions.

\section{Women-Headed Households}

Increasing numbers of women head their own households, either by choice, or more often because of divorce, desertion, or abandonment, and frequently because of temporary or permanent male outmigration (Table 4).

The average proportion of women-headed households is highest in the Caribbean (35\%). Rates average $20 \%-24 \%$ in the majority of other regions $(24 \%$ in the developed countries, $21 \%$ in Latin America, and 20\% in sub-Saharan Africa). The lowest average rates (12\%-13\%) are in northern Africa, western Asia and southern Asia. In southeastern Asia and Oceania the rates are 17\%-18\%. In sub-Saharan Africa there is considerable diversity, from $10 \%$ in Niger and Burkina Faso to $46 \%$ in Botswana and $40 \%$ in Swaziland (UN 1995).

Table 4. Women-Headed Households, 1990 Census (percent)

\begin{tabular}{|l|l|}
\hline Developed Regions & $\mathbf{2 4}$ \\
\hline Africa & \\
Northern Africa & 13 \\
Sub-Saharan Africa & 20 \\
\hline Latin American and Caribbean & \\
Latin America & 21 \\
Caribbean & 35 \\
\hline & \\
\hline Asia and Pacific & \\
Eastern Asia & 21 \\
Southeastern Asia & 18 \\
Western Asia & 12 \\
Oceania & 17 \\
\end{tabular}

Source: UNDP (1995)

As a result of heading their own households, increasing numbers of women have assumed new roles. "An historical process of women undertaking "male"tasks and working in "male" sectors in the absence of men has been reported for a number of societies" (Fortmann and Rochelieu 1985).

Even in male-headed households, women are taking on nontraditional roles and seeking to improve the productivity of traditional tasks as, on the one hand, markets change and the demand for women's traditional products declines; and on the other, women need cash to purchase basic items like soap and food. In fact, "there are no hard and fast rules about what men's activities are and what women's activities are," as Carr (1984) states, citing traditional examples of women blacksmiths in northern India, 
male weavers in Africa, and both male and female potters. She gives examples where women have been successfully trained and employed in a number of nontraditional trades such as welding and carpentry in Jamaica, in metalwork in Bangladesh, and as roofing-sheet makers in Kenya.

The lesson for renewable energy projects is that "male" roles are not fixed but are increasingly being undertaken by women household heads, as well as by other women. Hence nontraditional roles for women could also be considered in renewable energy projects.

\section{Energy Professions}

Women are also increasingly participating in the energy professions, due both to women's increased access to science and technology education, and to equal opportunity policies by institutions and governments. In the U.S. National Renewable Energy Laboratory (NREL), fully half of professional staff are women (Farhar 1997). In most energy institutions, however, the participation of women is still relatively small. Still, it has increased significantly in the past few decades. In Latin America, the number of women participants in an energy training course given by the Institute for Energy Economics in Bariloche, Argentina, has risen steadily from $10 \%$ in the 1970 s to $17.2 \%$ in the 1980 s and $23.5 \%$ in the 1990s (Torres 1998).

The technical roles filled by women include, for example, chemical engineer in the Ministry of Energy in Zimbabwe, an electricity economist in the electricity authority in Lesotho, an energy statistician in a research institute in Argentina, the head of an energy appropriate technology institute in the Philippines, and an oil exploration geophysicist in Pakistan. Women are responsible for funding energy projects in the Dutch, German, and Norwegian development assistance agencies. They have been managing energy programs in nongovernmental organizations and providing technical training in improved stoves in Kenya and in solar home systems in Vietnam.

Still, professional women face many obstacles in the energy sector. While practical concerns such as the "glass ceiling," sexual harassment, and limited training opportunities have predominated in many discussions among women employed in the energy sector, more general conflict may also exist in how women and men view energy problems. As Pryanthi Fernando acutely observes in advising young women starting their careers (Clancy/Fernando 1998):

... Energy and transport areas have been male dominated for so long, that it is easy for women going into these areas to take on the same perspective and dismiss, as irrelevant or "unscientific" or "unprofessional," the innate challenges to the system that they must feel from their own life experiences. It won't do them much good in their careers, either, if they take to challenging the status quo. So nothing changes. I would urge women starting their careers not to be overwhelmed and to take a critical look at the assumptions that dominate the thinking in their fields.

The increasing numbers of professional women in the energy sector can be a source of support and role models in efforts to increase the role of women in renewable energy.

\section{Some Experiences Involving Women In Renewable Energy Projects}

What then has been the experience with involving women in renewable energy activities? To date, such experience is fairly limited and information about it is anecdotal. Documentation is sparse and more information is needed on women's roles in renewable energy projects to date. Still, given the 
opportunity, women have in a number of cases demonstrated their interest by taking active roles in renewable energy projects that produce real benefits for them by improving their quality of life, reducing their workload in subsistence activities, or providing them with opportunities to increase their incomes.

As energy consumers and end-users, women have contributed to the design of household energy technologies and projects. As extension workers and caretakers, they have been effective in operation and maintenance roles. As micro-entrepreneurs, they have used renewable energy to increase profits and efficiency in their informal sector enterprises, and marketed renewable energy technologies, as well; and as leaders, networkers, and lobbyists, they have influenced energy policy decisions at the local, national, and international levels.

\section{Consumers and Beneficiaries}

Since women are the principal household energy consumers, the need to obtain women's input to product design and to target marketing and credit to women seems obvious. This lesson has been learned the hard way in improved stoves programs (Box 3).

In project after project, women have shown their ability to provide useful input to improved stove design, as in an urban stove project in Addis Ababa, Ethiopia, where women made the following comments:

- This stove is good ... you can take it anywhere.

- I'd like to have a door to regulate the winds.

- I am afraid it will topple over, the legs seem to be unstable.

- What about the pot support? Small pots will slip in.

- Could something be done to hold the wood in place?

- I used broken pottery to keep the small twigs from falling off.

- This stove will not last as long as a charcoal stove; it is made to burn firewood and if you char the embers with water it is bound to rust.

- I think it should accommodate the big absit pot, since we use that to prepare our bread dough every few days. (ILO 1987)

Such experience in involving women in household energy projects has been applied in some renewable energy projects. For example, an ongoing solar cooker test project in South Africa has carefully consulted women on the performance of various solar cooker models and their preferences (Palmer Development Group [PDG] 1997b). Table 5 shows the outcome of women's assessment of different solar cooker models in one village. Still, women could not choose between solar cookers and other energy or non-energy interventions.

Energy products that have been designed together with the end user are more likely to be accepted and thus to produce the expected benefits. If women do not use an "improved" technology, then they can derive no benefits from it. "Rural women have the ultimate weapon. They can refuse to use the facility," as Narayan-Parker (1988) says of hand pumps.

Of course, the lack of women's involvement is one reason why a technology is not used. Other reasons are lack of repair and maintenance infrastructure; it may not work as well as traditional technologies that do the same task; it may not fit with women's work schedules, time constraints, or physical capacities; or it may be monopolized or coopted by men. 
Box 3

\section{End-User Input to Stove Design Found to be Critical}

When household energy was first identified as a major energy sector in the 1970s, the first response was to look for a "technical fix": the introduction of "improved" wood and charcoal stoves. Most improved cookstove interventions in the 1970s initially were not based on a prior analysis of local and national fuel use and supply conditions. Where data were collected, projects frequently relied on the limited information base of men, even though women, as major actors in cooking fuel use and supply, often had knowledge about energy that men did not.

Many improved cookstoves were designed by male engineers without adequate consultation with women who would have to use them. Many professional technologists found it difficult to elicit, acknowledge, use, and respect women's traditional knowledge and expertise in the properties of fuels, food preparation, stove construction, and community education, all relevant for stove design and dissemination.

The result was very poor fuel saving performance and limited adoption of the new stoves. Stove engineers puzzled over why women frequently rejected the new fuel-saving stoves. Eventually it was found that even where fuel is costly, other interests such as cooking tasty food, saving cooking time, reducing smoke in the kitchen, space heating, and child safety are of equal or more concern to women as fuel saving. Yet, initially at least, the primary, if not the sole, objective of most cookstove programs was to increase energy efficiency.

Even worse, when testing moved from the laboratory to the kitchen, many so-called improved stoves were shown to be less efficient than well-managed traditional fires and stoves. The focus on stoves as an engineering improvement had neglected women's own stove-building experience, how new stoves and fuels fit into women's work, cooking schedules and priorities, and possibilities for raising cooking efficiency by analyzing and improving upon the coping strategies already used by women in the context of the entire food and cooking system.

The failure of so many "improved" stove projects to save fuel or disseminate large numbers of stoves led to a re-examination and, in many cases, a re-orientation of this strategy. Most improved stoves projects now integrate women's concerns about time saving, smoke, and income-earning, and involve women as project staff and women's organizations as partners. Today, although types of participation vary, it would be difficult to find an improved stove program in which women did not play an important role.

Source: Cecelski (1993)

Sale on a commercial basis is not the complete answer. Purchase of a product does not guarantee its use, only its presence in the home. How many of us own products that we seldom or never use? Sub-optimal levels of functioning and use have been documented in various countries for biogas plants, improved wood stoves and solar cookers that had been paid for by the owners. In some cases these remain prestige products purchased by higher-income households but rarely used. Only an estimated $66 \%$ of purchased biogas digesters in one study in India are both functional and used, for example (Dutta, et al. 1997). Thus it could be possible for market-oriented strategies to succeed in meeting sales targets yet fail in meeting critical energy needs or producing energy savings. 
Table 5. Voting Results by Focus Group Participants, Six Solar Cooker Models, on Self-developed Criteria, Onseepkans, Northern Province, South Africa

\begin{tabular}{|l|c|c|c|c|c|c|}
\hline \multicolumn{1}{|c|}{ Voting Criteria } & Sunstove & Ulog & REM 5 & REM 15 & SK 12 & Schwarzer \\
\hline Tile safest stove & & 13 & & & & 1 \\
\hline $\begin{array}{l}\text { The stove that cooks } \\
\text { The fastest }\end{array}$ & & 3 & 3 & 4 & 4 & 2 \\
\hline $\begin{array}{l}\text { The stove which 1 } \\
\text { am going to buy }\end{array}$ & 15 & 1 & & 5 & 2 & 1 \\
\hline The slowest stove & & 2 & 1 & 5 & 5 \\
\hline $\begin{array}{l}\text { The stove that cooks } \\
\text { the tastiest/nicest } \\
\text { food }\end{array}$ & & 9 & & 3 & 3 & 1 \\
\hline The prettiest stove & & 2 & 5 & 2 & & \\
\hline $\begin{array}{l}\text { The stove that you } \\
\text { can use for ironing }\end{array}$ & & & & & & \\
\hline $\begin{array}{l}\text { The stove that is the } \\
\text { easiest to move } \\
\text { around }\end{array}$ & 16 & & 15 & & & \\
\hline $\begin{array}{l}\text { The stove that is the } \\
\text { easiest to carry }\end{array}$ & & & & & & \\
\hline $\begin{array}{l}\text { The stove that you } \\
\text { cannot use in windy } \\
\text { conditions }\end{array}$ & & & & & & \\
\hline
\end{tabular}

Source: PDG (1997a)

\section{Benefits of Well-Designed Programs}

Where women end users have been involved in design of improved household energy technologies and projects, significant benefits to women in terms of fuel savings and time savings in fuel collection and cooking have been reported. In a Bamako, Mali, household energy program, households who use new stoves correctly save an average of $33 \%$ less wood. Users in Kenya saved 3 hours to 20 hours on gathering fuelwood, or if purchased, $40 \%-50 \%$ of the cost of fuel wood. Smoke emissions were reduced by a factor of 2.6. The household energy program also produced additional income opportunities for craftspeople, increased the readiness to innovate and strengthened the self-help potential by women's groups, and caused users to spread environmental awareness to non-users (Household Energy Program [HEP] 1993).

In Nepal, cooking with electricity from micro-hydro power schemes contributes to the reduction of the fuelwood collection burden on women by as much as 30\% (ITDG 1998). Biogas user families in India saved as much as four hours per fuel gathering trip and average 31 of trips per year compared with 40 for nonusers. This was in addition to saving about one hour per day in cooking time as compared to nonusers (Dutta, et al. 1997).

In a comparative test of seven manufactured solar cooker models in South Africa, households used 33\% less paraffin (kerosene), 57\% less gas, and 36\% less wood, representing considerable cost and collection 
time savings. Perhaps as important, women cited time-saving in cooking because, though total cooking time was longer, food could be left for long periods unsupervised as it did not burn (PDG 1997b).

On a macroeconomic basis, rough estimates of the economic value of the environmental and health benefits of improved stoves typically show a payback to society in only a few months, even at modest levels of acceptance and use (World Bank 1991b cited in Barnes, et al. 1994). In Rwanda, the cost of the program was $\$ 320,000$ over three years, and the estimated savings per year thereafter, excluding environmental benefits, were $\$ 895,000$. Studies of Gesellschaft für Technische Zusammenarbeit (GTZ)supported household energy projects in three Sahelian capitals found that the use of improved stoves had reduced the total fuelwood consumption of Ouagadougou by $8.1 \%$, Niamey by $2 \%$, and Bamako by $6.4 \%$ (Habermehl 1994).

\section{Different Perceptions of Benefits by Women and Men}

Women and men often show a considerable difference in their perception of benefits of new energy technologies. Figure 3 shows benefit perceptions in the Indian biogas program referred to earlier. Both men and women value time saving. But "even in the case of the time saving aspect, while most women spoke of time saved in fuel collection and cooking (which they can now devote to their families), the men were more concerned about faster cooking and timely meals. Women attached considerable importance also to the smoke-free environment in the kitchen and other associated health benefits followed by fuel saving and cleanliness (clean kitchen walls, ease in cleaning vessels, etc.). On the other hand, men ranked fuel and money savings high, while smoke-free environment was considered only a secondary benefit. Most men gave less importance to the cleanliness aspect" (Dutta, et al. 1997, p. 24).

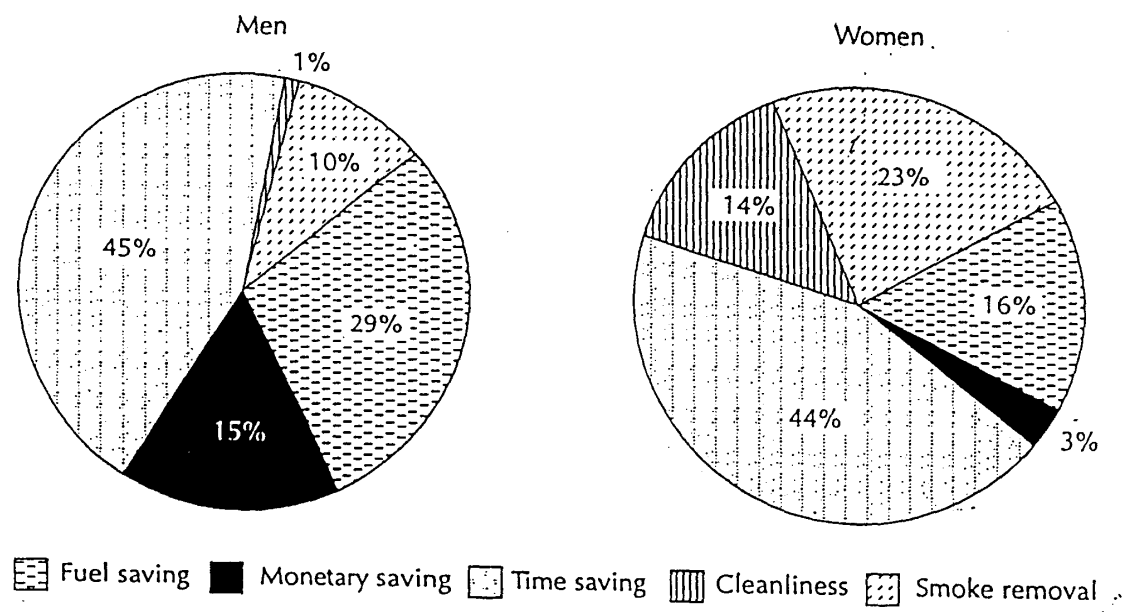

Figure 3. Benefit Perceptions by Gender, NGO Biogas Programs, India

Source: Dutta, et al. (1997)

These differing perceptions are not necessarily in conflict; women's and men's interests in uses of energy technologies may complement one another. Nonetheless, these differences have implications for priority end uses and marketing. 


\section{Affordability of New Technologies}

Can women afford to purchase improved household energy technologies? Gender analysis would show that in many instances men make the decision about major household purchases, even stoves. While the opportunity cost of women's unpaid labor remains low, they and their families will not consider labor saving a priority. Nathan (1997) explains the enormous difference between China and India in the success in commercial dissemination of improved stoves partially through these economic factors. By the early 1990s, 150 million (or 70\%) of farm households in China had adopted improved stoves sold at commercial prices, yet in India only $15 \%$ of households had adopted improved stoves, even though the stoves were offered at highly subsidized prices. This difference in success rate has been attributed to central planning and reliance on numerous layers of bureaucracy in India, with a resulting failure to address user needs for smokelessness, convenience, fuel savings, and subsidies (Barnes, et al. 1994).

Nathan suggests another reason, as well. In the rural areas of China with the highest adoption rates, a high level of village-level industry and commercial production of livestock and vegetables occurs with substantial participation by women. Rural areas of India, however, show low participation in moneyearning activities by women in farm households. Women's access to income-earning opportunities (and thus the value of saving time in fuel collection and cooking with improved stoves) may thus help to explain the difference in adoption of improved stoves.

Engaging in income-earning activities may in fact be the only way that many women can afford to purchase labor-saving energy technologies for their households. Do renewable energy technologies offer a means of improving women's productivity and income in their microenterprises?

\section{Microentrepreneurs}

Women have proven themselves capable of operating and also constructing renewable energy technologies on their own, when provided with the appropriate training and support. A key factor appears to be the ability of the renewable energy source to generate income for the users.

For example:

- In Uganda, an FAO/UNDP post-harvest program recommended small-scale solar dryers for long-term storage and household consumption of fruit and vegetables. Rural women's groups were more interested in solar dryers for income generation than for food security. The Fruits of the Nile company was formed in 1992 to link rural producers with the market for dried fruit in Europe. Within three years, more than 50 groups had taken up the solar dryer technology, and, in 1995, the company exported more than 50 tons of dried fruit. The original food security concerns are also being addressed. The women use the solar dryers to preserve vegetables and fruits for home storage and consumption when they are not drying for profit (Okalebo and Hankins 1997).

- In Sonora, Mexico, a group of women from one of the poorest neighborhoods, calling themselves Mujeres Activas, was looking for a micro-enterprise that could help support their families. They had already started using solar ovens in their families, so with assistance from an outside NGO, Mujeres Activas built large commercial-size solar ovens and established a bakery business that provides them with income to buy shoes and clothes for their children and send them to school (Stone 1998). 
- Thirteen women's groups, involving 200 people, have been trained in making stoves in the Rural Stoves West Kenya project, and many have also benefited from business management training. Annual production is estimated at 11,000 stoves; the profit generated by the stoves is comparable to wages in rural areas. As a result, the women potters have gained in status, self-confidence, and financial independence (ITDG 1998).

Carr (1984) argues that a valid reason for having women involved in the manufacture of producer goods such as food processing, cooking, and lighting devices, is that very often it is women who are the users of such devices. In a case study in the Sahel, for example,

... Women users preferred the stoves made by women to those made by men and, in fact, stopped using the latter. It makes sense that women, who spend their whole lives in processing crops, preserving food and collecting and carrying water, firewood and other commodities, should have a better feel for adapting equipment used in these tasks to specific needs and preferences than do men. Certainly evidence from the Sahel suggests that wood-saving stoves would be more widely in use by now if a start had been made sooner in teaching women artisans the basic scientific principles of improved stove making (Carr 1884, pp. 119-20).

Reddy (1996) has pointed out that women themselves are logically the most appropriate renewable energy entrepreneurs for household and small-scale industry needs. Not only are women the victims of energy scarcity, and the potential beneficiaries of energy interventions, but they are also already managers of fuel-intensive informal sector enterprises themselves. Hence, women may also be effective energy entrepreneurs.

Women already have a track record of functioning as effective entrepreneurs in visibly successful organizations and networks like Grameen, SEWA, ${ }^{4}$ etc. The challenge is to transform them and their organizations into energy entrepreneurs (Reddy 1996, p. 13).

Indeed, the Grameen Bank, which provides small credits to mostly women entrepreneurs in Bangladesh, has recently launched Grameen Shakti, which will market photovoltaic systems and eventually other renewable systems (Barua 1998).

Women's organizations have also become involved in marketing and administering renewable energy systems. The Vietnam Women's Union (VWU), a nationwide social-service organization, has been active in the promotion of solar home systems, supervising motivators who sign up households and administering a revolving credit fund. The Solar Electric Light Fund (SELF) designed the project, provided initial funds, imported the solar systems, and provided training. The systems were installed by Solarlab (South Vietnam) and the Energy Institute (North Vietnam), with the assistance of local technicians, many of them women. The role of the VWU was to promote the systems in rural areas through its extensive network and to collect the down payments as soon as a family signed up. Later, the VWU was to collect monthly payments of the users in remote villages (Everts and Schulte 1997).

\footnotetext{
${ }^{4}$ The Self-Employed Women's Association, an organization to improve conditions of micro-entrepreneurs in India.
} 


\section{Operation and Maintenance (O\&M)}

With decentralization to the lowest appropriate levels, many of the operation, maintenance and repair tasks for RETs are delegated to communities or local institutions. The high cost of servicing renewable energy installations in remote areas is a frequently-cited constraint to dissemination. Yet regular maintenance and repair are key to functioning and use of renewable energy technologies. Usually these tasks have been seen as purely technical and a male prerogative. Typically, men or boys have been trained and employed in the maintenance of renewable energy technologies, even when the main beneficiaries and users have been women.

However, if we look at the extensive experience with women in maintenance roles in water and sanitation projects, women's effectiveness in regular and preventive maintenance is better than men's, and costs of repair campaigns are lower (Wakeman 1995). This is because women use water facilities more than men, and hence have a direct interest in their continuous operation. Some costs may be higher because of women's need for more training and their restricted mobility, which reduces the number of pumps they can maintain.

The UNDP/World Bank women, water and sanitation program has successfully combined low-cost handpump development with community involvement in O\&M, especially by women. In a typical project in Kenya

. . . in early 1988, all pumps were functioning and were being looked after by usercreated water committees. All the committees (125) include women, have women as treasurers, and all collect cash. A majority, 70\%, have already opened bank accounts. This money has been used to buy spare parts and correct pump breakdowns (NarayanParker 1988, p. iv).

Local women were trained as extension workers and as pump caretakers. Training of even nonliterate, older village women and men in O\&M of pumps proved possible. Moslem women, whose abilities had been doubted at the beginning of the project, not only became effective extension workers but also played prominent roles in village level activities.

Similar results may be expected with solar home systems and other renewable energy technologies that seek to address household needs. Winrock International's Latin American renewable energy program has found that women in many rural areas are effective at PV maintenance because they are more likely to be at home and in the community during the day as they care for small children. "As a result, women are more interested in the acquisition and successful operation of products that enhance quality of life in the home, such as illumination and potable water" (Kennedy and dos Santos 1998, p. 7).

Two Winrock projects illustrate these principles. In Guatemala, equipment maintenance and accounting for the replacement of batteries in PV home systems was aimed at women, since they were at home more and used the systems more than men. Women were amenable to mini-training sessions at home because their work schedules and responsibilities in the home, as well as cultural traditions, suited this arrangement. The women could practice on their own systems, rather than viewing diagrams or learning from watching their husbands; and the women felt more free to participate and ask questions during the daytime training sessions while their husbands were out in the field (Wides 1998).

In Brazil, women's involvement in 13 village solar pumping projects in Ceara, the third largest northeastern state, proved to be highly successful. Women's participation in the maintenance of wells 
was integrated with education on health matters related to drinking water, childcare, etc. This participation was the key factor in the trouble-free operation of the solar pumps for the past six years and the effective enhancement of public health in the villages where the pumps were installed (Kennedy and dos Santos 1998).

An in-depth evaluation of the Indian NGO biogas program by the Tata Energy Research Institute (TERI) found lack of user awareness and training was a major factor in sub-optimal operation of the plants. One conclusion was that involving women in monitoring and repairs was an effective repair and maintenance strategy. In one NGO,

A user group of women is formed in each village trained to carry out minor repairs such as stove repairs, leak testing, etc. While all expenses for repairs are borne by the beneficiary, it is ensured that the mason who has constructed the plant also repairs it. It needs mention here that the system is functioning well because it is backed and monitored closely by the village-level mahila mandals [women's groups]. In case of a major fault, the mukhya mahila [women's group leader] of the village approaches the centre either by post, or during the monthly meetings which are held for all the mukhya mahilas. Besides, the field staff of the centre visit each village at least once every month (Dutta, et al. 1997, p. 60).

Nonetheless, the same study found that though women are the primary users of biogas, in most projects they have only a marginal role in the implementation process. While all the NGOs emphasized the need to involve women at every stage of the program, the situation at the field level was vastly different. Table 6 lists various activities identified by the study, in which women's role would be desirable, and compares this with the present situation. Clearly, there is room for improvement.

Involvement of women in biogas installation and management can easily be imagined as an extension of their traditional household responsibilities for waste management and health. Health, for example, has been an entry point for women's involvement in latrine construction in many countries, with an abundance of cases where female masons promote, market, and build latrines. Training in masonry work builds on women's traditional tasks and skills in plastering (van Wijk-Sijbesma 1998).

ITDG has noted increasing participation, though still small, by women in its micro-hydro projects. In Sri Lanka, village hydro schemes may be leading to changes in the decision-making role of women. The power houses for two micro-hydro schemes are overseen by women who also carry out basic operational duties. In at least five of the 35 electricity consumer societies, women members have become secretaries, and one is a treasurer. In Peru, milling activities are traditionally undertaken by women and, therefore, the improved mill technology tends to benefit women in particular. Even the hydraulic milling systems are operated by women. These are always located near the homes of the families who own them. As women stay close to home, they usually take over the control and management responsibility. For this reason, three workshops have been held to train women to manage these systems (ITDG 1998).

\section{Management and Influence}

Women do not necessarily have to build, operate, or maintain renewable energy installations alone, in order to benefit. More important is that women have a role in determining the use and benefits of the project and in managing these arrangements, and that they receive and control benefits. This is why, in addition to analyzing separately what women and men do, it is important to look at the ways they work together in energy activities such as construction and maintenance and household decision making. The 
Table 6. Role of Women in NGO Biogas Programs in India, Desirable Role and Existing Situation

\begin{tabular}{|c|c|c|}
\hline Role of Women in: & Desired Role & Existing Situation \\
\hline Planning & $\begin{array}{l}\text { Decision-maker for adopting } \\
\text { Technology and selecting } \\
\text { Appropriate site for biogas plant. }\end{array}$ & $\begin{array}{l}\text { The decision to install a biogas plant is } \\
\text { taken by men except in cases where } \\
\text { women have been involved through } \\
\text { village-based institutions in motivation. }\end{array}$ \\
\hline Construction & $\begin{array}{l}\text { Need to be aware of the type, } \\
\text { quality and quantity of } \\
\text { material used for construction. }\end{array}$ & $\begin{array}{l}\text { The women are completely unfamiliar } \\
\text { with the construction-related aspects } \\
\text { such as material requirement, technique } \\
\text { used, etc. }\end{array}$ \\
\hline $\begin{array}{l}\text { Operation and } \\
\text { maintenance }\end{array}$ & $\begin{array}{l}\text { As primary users, women should be } \\
\text { familiar with: } \\
\text { - The functioning of the biogas } \\
\text { plant; } \\
\text { - Proper method of feeding dung } \\
\text { and water; } \\
\text { - The procedure for removing } \\
\text { water from the pipeline; } \\
\text { - Method of cleaning stove } \\
\text { components like knobs and } \\
\text { burner; and } \\
\text { - Minor repairs like replacement of } \\
\text { washer, teak, etc. }\end{array}$ & $\begin{array}{l}\text { Except for operating the stove, they have } \\
\text { incomplete information on all major } \\
\text { aspects related to operation and } \\
\text { maintenance. }\end{array}$ \\
\hline $\begin{array}{l}\text { Role of women } \\
\text { staff as } \\
\text { motivators }\end{array}$ & $\begin{array}{l}\text { Should have a thorough knowledge of } \\
\text { the technical and related aspects like } \\
\text { functioning of a biogas plant and } \\
\text { advantages of the technology. }\end{array}$ & $\begin{array}{l}\text { Are generally poorly informed due to } \\
\text { lack of adequate training. }\end{array}$ \\
\hline
\end{tabular}

Source: Dutta, et al. (1997)

interrelationships between men and women in a community and in other organizations also bear examination.

Although conflicts and differences of interests between women and men can and do exist, men often support the efforts of women to save time and improve their families' welfare. Even in a Muslim country like Yemen, the openness of both women and men-to-women's role in renewable energy was evident in a baseline survey for a biogas project: It revealed that women were ready to acquire new skills and knowledge that would improve their lives and that of their families. It also indicated that the male heads of households welcomed the release of women from their difficult tasks, within and outside the home, and the utilization of the time for education and improvement of family conditions (Obaid and Saleh 1997). 
As the PROWWESS project manager points out,

The importance of women goes beyond the question, "How many women should be trained as pump caretakers?" The key issue is women's involvement in decision making and management in ways that enhance human capacity and hence sustainability, and also generates ownership of projects (Narayan-Parker 1988, p. vi).

This appears to have been the case in a micro-hydro electric system installed by a peasant organization in Peru, for example, where men, women, and even children provided labor to construct the civil works, and male engineers designed the system and operate the electro-mechanical equipment. Women's influence in the decision making is evident in the choices of use for the electricity generated, though - a grain mill for wheat, maize, tarwi, and canihua, to alleviate one of the most laborious tasks for women, graingrinding; and posts for public lighting, which improve safety, frequently a major concern of women. In fact, women were not only represented in the cooperative, but a woman from the village was elected as the first female mayor in the region during the project period, and the president of the cooperative is a woman (Oliveiros 1998).

In this and other renewable energy projects, there is evidence that women's status in communities has increased as a result of their involvement in renewable energy schemes.

Involvement in energy projects can also raise the status of women's organizations and bring them into the energy policy arena. For example, now that the Vietnam Women's Union (VWU) has shown that it has been able to implement rural electrification projects, it has become a factor in the energy sector. The project brought VWU into the energy sector, and it can now use this position to influence future energy planning (Everts and Schulte 1997). 


\section{Will Women Automatically Benefit from Renewable Energy Technologies?}

Rural women are often assumed to be the principal beneficiaries of "improved" technologies, in particular of renewable energy technologies. Labor-saving devices are clearly a priority for rural women, given the inordinate amount of time and energy that they expend in necessary household drudgery. Two phases in rural technology initiatives can be identified that have had gender effects: those introduced to improve efficiency of production in general, and those aimed specifically at reducing women's drudgery. ${ }^{5}$ Unfortunately, numerous studies have shown that not only have many labor-saving technologies failed to save women's time and energy, but they have sometimes even worsened women's social and economic conditions. Can renewable energy development learn from and improve on this experience?

\section{Technologies to Increase Efficiency: The Green Revolution}

The Green Revolution in the late 1960s and early 1970s, while directed at raising efficiency and productivity in general, had unforeseen impacts on women. "The short-term impact of productivityenhancing technologies on women was usually non-existent, whereas the medium and long-term effects were frequently negative." (Bryceson and McCall 1997, p. 31 ) Because technologies were aimed at the male head of household, who already controlled legal and cultural rights to land, water and other resources, the ability to organize hired labor, and the legal prerequisites for credit, the introduction of new technologies in most cases simply exacerbated the situation (Bryceson and McCall 1997).

One common pattern "was for 'traditionally' male tasks to be mechanized before traditionally female tasks: ". . . In the Green Revolution, the male tasks of clearance, land preparation, and planting were mechanized by animal- or tractor-drawn equipment, whilst female tasks of weeding and harvesting, and transport to and from fields were not" (Agarwal 1985, p. 32). Similarly, women's human energy tasks such as drinking water provision, fuel collection and food processing have received minimal attention in terms of improved energy technologies, even though these are necessary for household production (and reproduction) to take place.

Furthermore, in the Green Revolution, wage labor tended to be mechanized for cost-efficiency reasons, with detrimental effects on women's earnings. "Traditional rice-milling in Java, Sri Lanka and Bangladesh involved hand pounding of rice, a drudgerous, labor intensive female task paid very low wage rates. This was almost totally replaced in a short period by mechanized milling employing mainly male labor. Thus, a drudgerous task was removed, but at great cost by placing women back into unpaid domestic work." (Agarwal 1985, pp. 32-33) In Indonesia on government initiative, mechanized rice hullers replaced $90 \%$ of manual rice hulling between 1970 and 1978, with estimates of jobs lost as high as 1.2 million in Java alone and 7.7 million in all of Indonesia as a result. It is estimated that the loss to women hand pounders in earnings due to the use of hullers was $\$ 50$ million (U.S. dollars) annually in Java, representing 125 million woman days of labor (Dauber and Cain 1981). Similar results with introduction of more efficient energy technologies are easy to imagine.

Carr (1984) has noted that when attempts are made to introduce improved techniques or technologies aimed at increasing productivity, the result can often be that men take over traditional women's industries. Once a new technology brings upgraded skills and higher returns, the men take over. Such outcomes have been noted more recently with palm oil milling in Nigeria and improved fish-smokers in

${ }^{5}$ This section draws heavily on an excellent review by Bryceson and McCall (1997). 
Senegal (Bryceson and McCall 1997) as well as improved gari processing in Nigeria (UNIFEM with ITDG 1989):

The high purchase cost of these [improved gari-processing] technologies has resulted in only men owning and operating these machines. With the introduction of mechanical graters and presses, work traditionally done by women became the work of men. This transfer of control resulted in a transfer of income. Women lost an important income source (UNIFEM with ITDG, 1989, p. 60).

In the Green Revolution, furthermore, because technical innovations were mostly taken up by more resource-endowed households, "the detrimental impact was most deeply felt by women from households which did not adopt the technology, especially the landless women deprived of their former employment. In Bangladesh for instance, whereas poorer households still husked rice with a pestle and mortar with much unpaid family labor, richer households hired mechanical rice huskers. Thus, the mechanization of harvesting and post-harvest processing displaced the poor hired women, whilst having a negligible effect on the women of richer households" (Bryceson and McCall 1997, p. 33).

Increasing the efficiency of production processes usually implies larger-scale production. Women producers, who are often part-time and small-scale, can easily be marginalized and lose control of the production process to male owners who can afford the necessary capital investment. In Ghana, for example, a World Bank pre-feasibility assessment found that most producers would benefit from a project aimed at improving the efficiency of making charcoal from sawmill wastes. However, smallscale itinerant producers were unlikely to be able to secure land tenure for fixed kilns, to invest in the new equipment, or to purchase the now more valuable residues. Although only about 300 charcoal makers would be affected, most of these small producers turned out to be women (Cecelski 1989).

\section{Technologies to Reduce Drudgery: “Appropriate” Technologies}

Even technologies aimed specifically at reducing women's drudgery have often not had the desired effect. In the next phase of technology interventions in the 1980s, "many agencies and local institutions aimed domestic technologies at women, and specifically at their unpaid domestic tasks with the intention of alleviating drudgery. Thus, they included crop and food processing technologies like grain mills, and water-lifting and distribution devices, especially hand pumps. It is notable that the burden of fuel collection was not considered until much later in the 1980s, and then normally through the production of more fuel supplies, and very rarely through improved technology for the collection and transportation of firewood" (Bryceson and McCall, 1997, pp. 33-34).

Even though these programs were directed at women, issues emerged: how should "appropriate" technologies be chosen? How can women get cash or credit to pay for domestic devices? Do women actually save time or labor, and how do they use the savings? Are there long-term benefits for women or changes in their social or economic status as a result of these technologies? Biogas is a good example, where fuelwood collection has been substituted by water collection. This was the reason women in Tanzania abandoned the technology despite the many other positive benefits they identified (Joy Clancy, personal communication 1999).

A number of approaches have gradually been developed to solve these problems, with appropriate interviewing such as surveys of women's and men's actual work activities and needs; participatory research using women's indigenous knowledge; and credits or subsidy schemes for purchase. Some of 
these have been applied successfully in energy-related interventions, notably in the household energy sector.

Where women show lack of interest in renewable energy projects, this may be due to the project's failure to produce benefits for them. Soma Dutta (1997) attributes the lackluster performance of interventions such as biogas and improved stoves programs in India, for example, to the poor level of involvement and lack of "stake" for the women in these programs.

Typically, the devices are designed and tested, and programs are implemented and monitored by men. Women's main role is that of beneficiaries or final users of the innovation. Even in interventions where there have been efforts to seek women's participation, their involvement is usually restricted to being 'data sources' or occasionally women are used to convince other women to use the biogas plants or the improved chulhas (Dutta, 1997, p. 12).

Successful projects have paid careful attention not only to technical feasibility, but also to factors outside the production process, such as access to raw materials (including land ownership and control over cash crops), access to credit, social and cultural context, management and organization, leadership, and marketing. Provision of credit and assisting women's groups in other ways have been the most effective strategies to enable women to own and profit from these larger-scale, more efficient processing technologies.

For example, a potato-drying project in northern India introduced only one technical change to the traditional sun drying - covering the product with fine netting to provide protection. The project then focused on storage systems, processing equipment, and a marketing organization for dried potato products. The result is a high-quality product and a substantial increase in market demand. In Peru, several technical innovations were introduced to a women's group in Huancayo to improve papa seca production: a mechanical peeler, metabisulphite to improve final product color, and a simple solar dryer. The group then could produce $450 \mathrm{~kg}$ per month, and its main problems became marketing, management, and lack of working capital (UNIFEM with ITDG 1993).

Financing renewable energy projects has proven to be one of the most important and difficult aspects of renewable energy programs. Credit is an especially critical constraint for women, whether as representative households or as entrepreneurs. Even though it has been documented in study after study that women have a better record of credit repayment than men, women still receive a disproportionately small share of credit from formal banking institutions. In Latin America and the Caribbean, women constitute only $7 \%-11 \%$ of the beneficiaries of credit programs. In many African countries, women account for more than $60 \%$ of the agricultural labor force and contribute up to $80 \%$ of total food production, yet receive less than $10 \%$ of credit to small farmers and $1 \%$ of total credit in agriculture. A study of 38 branches of major banks in India found that only $11 \%$ of borrowers were women (UNDP 1995).

Most banks require that borrowers be wage-earners or property-owners with acceptable collateral, conditions that women often cannot meet. Limited education, complicated loan procedures, and long distances to the nearest bank further constrain women's access to credit. Lack of access to credit is thus a major constraint on women's purchase of renewable energy technologies. 
Box 4

"Improved" technologies not always appropriate without women's traditional knowledge and needs assessment

Inadequate needs assessment and attention to local knowledge have frequently resulted in the transfer of "improved" technologies that were inferior to traditional methods. Numerous examples from the introduction of food-processing technologies confirm this.

In Tanzania, for example, an imported hand mill was judged unsatisfactory for grinding maize, since the process by which flour of an acceptable quality could be acquired was long and tedious (involving several siftings and regrindings) and was not considered an improvement on the traditional method. A millet dehuller introduced to women's groups in Senegal produced more broken grains than hand dehulling. Imported millet mills in Senegal were criticized by women for not being capable of handling wet grain, desired for its taste, and for clogging (UNIFEM with ITDG 1988a).

An "improved" fish smoking oven introduced in Sierra Leone was rejected because it could not handle the large volume of fish processed by fish mammies as well as a modified traditional oven (UNIFEM with ITDG 1988b). In Burkina Faso, a groundnut oil press introduced was heavy, and hard to clean, and did not provide a desirable by-product of oil production, kuli-kuli groundnut cookies, whose sale gave women actually a bigger profit from the traditional method than selling the oil itself (UNIFEM with ITDG 1987).

In Sierra Leone, a woman-oriented project attempted to introduce a new palm oil press. Problems included the following:

- The machine was reported to be too small; there were no time savings; output was actually lower than that obtained with the traditional method; the machine was not easily operated by women and the process used more firewood - a scarce commodity - than before. In total, the new "improved" press was firmly rejected by the villages in the pilot scheme.

- Once the prototype had been designed, the university staff were unable to produce the required numbers for testing. Their priorities were to teach and develop new projects, not to manufacture the equipment itself. Most of the presses arrived too late for the main harvest. No arrangements had been made for scaling up for commercial manufacture and distribution to supply the demand generated (King-Akerele, cited in Carr 1984). 


\section{Why Is a Gender Perspective Relevant in the Energy Sector?}

\section{What Is a Gender Perspective?}

The gender perspective recognizes that some issues and constraints related to project success are genderspecific, and stem from the fact that men and women play different roles, have different needs, and face different constraints on a number of different levels. A gender perspective is useful because it can help ensure that women receive benefits from the development process; that they do not suffer from unintended negative impacts; and that women can contribute most effectively to the success of the development activity. Of course there are various factors in success and failure. But many examples can be given of development projects that have simply failed in their goals, at least partially because they ignored women's needs, constraints and contributions.

Gender analysis is a methodology that seeks to understand the distinct culturally and socially defined roles and tasks that women and men assume both within the family and household system and in the community. Sex as male and female cannot be readily changed. However the tasks that men and women are responsible for in different cultures can vary. Charcoal-making, pottery-making and weaving are some examples of activities that in some cultures are typically done by men, and in others typically by women. Gender analysis seeks to assist in planning development activities, by improving understanding of these different gender-specific roles and responsibilities.

A number of texts and training manuals are available on gender analysis, most of these drawing on the Harvard Analytical Framework developed by the Harvard Institute for International Development. The framework has four parts: (1) an activities profile, (2) a profile of access to and control over resources and benefits, (3) a profile of factors influencing the first two profiles, and (4) a project cycle analysis. Each profile gives information for each gender. The project cycle analysis inputs the data from the profiles analyses into the project process.

Gender analysis has been used for many years by organizations ranging from Oxfam to the World Bank. There are many examples of its successful use in agriculture, in water and sanitation, and in community forestry (FAO/FTTP 1995; Wakeman 1995; Murphy 1997). Why has gender analysis not been adopted more extensively in the energy sector?

In the conventional energy paradigm, women have not necessarily been excluded intentionally nor their energy-related activities overlooked; they have simply been defined out of the energy sector. In the paradigm dominant until recently, "energy" was defined as large-scale, capital-intensive technology projects run by professional experts for the purpose of providing energy for "economic growth." Energy thus consists solely of inanimate fuels rather than the actual definition of energy as the capacity for doing work and overcoming resistance. "Energy" in the dominant paradigm has emphatically not been smallscale, management-intensive activities done by women using their own muscle power or local natural resources, either for family subsistence or small-scale income activities. Not only women, but people and socio-economic issues in general have been largely ignored in energy planning and policy until fairly recently. The energy sector has been defined as (Cecelski 1992):

- Capital-intensive, large-scale and commercial activities. Despite rhetoric about alternative energy and fuelwood, nearly half of the Organization for Economic Cooperation and Development (OECD) official development assistance (ODA) to the energy sector in developing countries from 1979 to 1982 was devoted to large hydropower and electricity transmission alone. Power plant construction, oil and natural gas exploration, development and transport, coal mining and nuclear energy took 
another share, with only $2 \%$ devoted to fuelwood, charcoal, geothermal energy, fuel alcohol, biogas and solar energy combined (OECD 1984). Until at least the mid-1980s, however, not only did the majority of energy assistance projects fail to address rural and poor livelihood issues, many had dire environmental consequences, including for women.

- High technology with high-level expertise. Not only conventional energy policy and planning, but also more recent work on energy efficiency, renewable energy sources and environment has sometimes fallen prey to the belief that technical "fixes" based on advances in scientific knowledge will solve energy and environmental problems. This belief continues, despite the fact that research has shown that the reason for most energy project failure is not lack of technologies, but rather institutional, socioeconomic, and cultural (see e.g. Putti 1998). Most technologists do not, in fact, dispute this finding, but still often tend to view people and their needs and concerns as constraints which must be overcome in order to successfully introduce superior technologies, rather than as the reason for technology development in the first place. Energy, by definition, is a highly technical field dominated by engineers, foresters, and energy planners. As the keepers of superior knowledge, it has sometimes been difficult for such professionals to elicit, acknowledge, use, and respect people's traditional knowledge, including that of women, or to see the value of social science knowledge to energy development generally.

- Inanimate fuels, not human energy. In conventional energy studies, one of the most damning concepts for women is the exclusion of metabolic human energy from consideration. Energy consists of oil, natural gas, coal, hydropower, nuclear, wind, solar, biogas and geothermal energy. It cannot be considered to include a human being performing the same tasks with muscle power as can be done with such fuels. By definition, most of women's energy-using tasks (carrying water, grinding grain) are not energy-sector concerns. This conclusion makes it possible for energy studies to more or less ignore potential improvements in most of women's work.

Of course, these reasons argue for, not against, increased use of gender analysis in the energy sector. And fortunately, recent developments are facilitating this happening.

\section{New Perspectives in Energy Policy and Gender Analysis}

Research, experience and networking on women and energy have been growing since 1981, propelled by several factors.

\section{Energy, Environment and Development}

Energy policy and practice have moved in the past two decades from a focus purely on technical, supply concerns, to embrace a broad range of new issues. The energy transition to more efficient fuels and technologies, development and sustainability issues, privatization and globalization, and, most influentially, rising concern over the relationships between energy and environment, have led to more focus on the role of energy consumers, social and economic factors in technology adoption, and impacts on people. Non-governmental organizations and stakeholders generally have become more accepted in energy policymaking with the rise of environmental consciousness and the global climate change negotiations. Now that people are more part of the energy equation, women are becoming more visible, too. 


\section{Gender and Development}

Gender paradigms have evolved from "women and development" (WID) in the 1970s, which focused on women in isolation (with limited success), to "gender and development" in the late 1980s, which seeks to understand the distinct culturally and socially defined roles and tasks that women and men assume both within the family and household system and in the community. This detailed analysis of distinctive (and differing) on-the-ground realities fits well with methodologies of demand analysis which also survey local conditions in order to establish energy needs.

Current gender perspectives mark a shift away from viewing women as passive recipients of science and technology and merely getting more women into the mainstream. Women are seen rather as active participants in the innovation process, through their knowledge of their distinct material reality and demonstrated innovative capacities. The incorporation of women is expected to shift the mainstream positively towards meeting needs of the poor, the South and women. In this sense, both new energyenvironment paradigms and current gender perspectives adopt a transformational approach, challenging conventional means and ends of development.

\section{Women in Energy Professions}

More women are employed in energy professions, due both to women's increased access to science and technology education, and to equal opportunity policies by institutions and governments. In most energy institutions, the participation of women is still relatively small, and professional women face many obstacles in the male-dominated energy sector. But there is starting to be a "critical mass" of women (and many men, too) in energy ministries, research institutes, field projects and donor agencies, who understand and support the need to involve women in sustainable energy.

\section{Higher Visibility Internationally}

Women's organizations have acquired a higher profile in international advocacy and policy in recent years, especially through their active role in the UN Conference on Environment and Development in 1992 in Rio. The Rio Conference, followed in 1995 by the UN Conference on Women in Beijing in 1995, gave an impetus to the movement to put women's needs and concerns on the international energy agenda. The time line in Table 7 shows how activities on women and energy have taken off, especially since 1995.

Since 1995, a number of workshops and meetings on women and energy have been organized, sometimes as part of energy conferences, more often freestanding; e.g., at meetings of the World Renewable Energy Congresses (WREC) in Denver and Florence, the International Solar Energy Society (ISES) in Harare and Korea, the African Development Bank (ADB) in Abidjan, the Latin American Organization for Energy and Development (OLADE) in Quito, the Center for Sustainable Energy (CASE) and the Indian energy ministry in Delhi, and the Winrock Foundation in Guatemala and Brazil.

Several major international energy institutions have recently initiated activities on women in their programs. The US NREL has initiated and is planning gender and energy research. The UNDP included gender as an essential development linkage to energy in Energy After Rio in 1997, and the new UNDP Sustainable Energy Global Program plans 20\% of core resources over the next several years for women and energy. A regional project on "Improving Women Entrepreneurs Access to Sustainable Energy in 


\begin{tabular}{|c|c|}
\hline 1981-1995 & \\
\hline 1981 & $\begin{array}{l}\text { * UN Conference on New and Renewable Sources of Energy, Nairobi } \\
\text { * The Real Energy Crisis: Women's Time (I. Tinker) } \\
\text { * Women \& Energy in the Sahel (J. Ki-Zerbo) } \\
\text { * Human Energy in Pura Village (A. Reddy) }\end{array}$ \\
\hline 1982 & * Energy \& Rural Women's Work Project launched (ILO/Dutch) \\
\hline 1984 & * Biomass Fuel Combustion \& Health (WHO/East-West Centre) \\
\hline 1985 & $\begin{array}{l}\text { * Community Forestry Unit est'd. (FAO/SIDA) } \\
\text { * Household Energy Unit est'd. (ESMAP/World Bank/UNDP) }\end{array}$ \\
\hline 1987 & $\begin{array}{l}\text { * Restoring the Balance: Women \& Forestry Resources (FAO) } \\
\text { * Linking Energy with Survival: Energy, Environment \& Women's Work (ILO) }\end{array}$ \\
\hline 1988 & * GTZ Household Energy Program established \\
\hline 1992 & $\begin{array}{l}\text { * Boiling Point Special Issue on Women, Woodfuel, Work \& Welfare } \\
\text { * Household Energy \& Development Network founded (HEDON) } \\
\text { UN Conference on Environment \& Development, Rio }\end{array}$ \\
\hline 1993 & * Women's Energy Group (WEG), South Africa founded \\
\hline 1994 & * Workshop on Women and Global Energy Policy, Dakar (IFIAS/IFAN) \\
\hline 1995 & $\begin{array}{l}\text { * ENERGIA International Network on Women \& Sustainable Energy founded } \\
\text { * Fourth World Conference on Women, Beijing } \\
\text { * Women and Energy group meets at ISES World Congress, Harare } \\
\text { * Wood Energy News Special Issue on Gender \& Wood Energy (RWEDP/FAO) }\end{array}$ \\
\hline
\end{tabular}

$\underline{1996-1998}$

1996 * Gender Analysis \& Forestry International Training Package (FAO)

* Gender Sourcebook for Water \& Sanitation Projects (UNDP/World Bank)

* Energy \& Environment Technology Sourcebooks Series launched (UNIFEM)

* First ENERGIA Support Group Meeting, Enschede, Netherlands

* Seminar on Role of Women in Sustainable Development, Abidjan (ADB)

* Symposium on Women in Sustainable Energy, WREC-IV, Denver (NREL)

* First Int'l Conference on the Role of Women in the Development of Sustainable Energy in Latin America \& the Caribbean, Quito (OLADE)

* Seminar on Renewable Energy: A Development Option for Women, Guatemala (Fundacion Solar/Winrock)

First issue of ENERGIA News published 


\begin{tabular}{|l}
\hline 1997 Workshop on Role of Women in Renewable Energy Development \\
(AIWC), Int'l Conference on Village Electrification, Delhi \\
(CASE/MNES) \\
$*$ Second ENERGIA Support Group Meeting, Amsterdam \\
$*$ Women \& Energy Workshop TDG/ENERGIA), ISES Int'1 Solar \\
World Congress, Korea \\
$*$ Seminar on Gender and Renewable Energy, Brazil (Winrock Fdn) \\
$*$ Gender in Energy Training Pack (U. Twente) \\
* Energy After Rio: Prospects \& Challenges includes gender (UNDP) \\
Issues 2-4 of ENERGIA News published \\
* UNDP Sustainable Energy Global Program: 20\% for women \\
$*$ Women \& Energy Sustainability technical sessions (NREL/CSC), and \\
Workshop on Women Entrepreneurship (AIWC), WREC-V, \\
Florence \\
* Issues 2.1-2.3 of ENERGIA News published \\
$*$ Central American Seminar on Gender \& Renewable Energy, \\
Guatemala \\
* Women \& Sustainable Energy Workshop, Village Power '98, \\
Washington, DC
\end{tabular}

Source: This timeline is based on one originally presented in Cecelski, 1996. A broader chronology of events in the development of gender and energy as a field 1970-1997 is available in Farhar 1998a.

Africa has been launched by UNDP/SEED. ISES has designated one of its women directors responsible for promotion of gender issues. The Winrock Foundation, together with its regional offices in Latin America, has initiated gender and energy workshops in Guatemala and Brazil.

\section{Training}

Training resources specific to the energy sector are being developed, for example the Gender and Energy Training Pack produced by the University of Twente, and the Energy \& Environment Technology Sourcebook series launched by UNIFEM. The University of Twente also offers training courses on gender and energy.

\section{Networks}

National networks on women and energy are also being established. A Central American network on women and sustainable energy has recently been established. The Women and Energy Group (WEG) in South Africa was founded in 1993 by women energy researchers at the Mines and Energy Policy Center (MEPC) in Johannesburg and the Energy Research and Development Center (EDRC) in Capetown. The Rural Energy Department of the All-India Women's Conference (AIWC) has an active network in the sub-continent and is on the board of the Indian Renewable Energy Development Agency (IREDA). In Canada, a national network is forming, and CIDA has supported a Petroleum Women's Network in Pakistan. 
ENERGIA, ${ }^{6}$ the International Network on Women and Sustainable Energy, was established in 1995 in The Netherlands as a means of linking individuals and groups concerned with women and sustainable energy, and encouraging them to identify and implement needed activities (ENERGIA 1998). ENERGIA and its newsletter, ENERGIA News, were seen as a first step towards developing a focal point around which activities on gender and energy could be implemented and catalyzed, and information related to gender and energy could be gathered, sorted, analyzed, discussed and disseminated. ENERGIA currently has about 1,000 members, of which about a quarter are men and three-quarters are women.

\section{Gender and Renewable Energy: The Way Forward}

This paper has shown that women are not a special interest group in renewable energy, they are the mainstream users and often producers of energy. Without their involvement, renewable energy projects risk being inappropriate, and failing. Women are the main users of household energy in developing and industrial countries; they influence or make many family purchases related to energy; they are experienced entrepreneurs in energy-related enterprises; and women's organizations are effective promoters of new technologies and active lobbyists for environmentally benign energy sources.

Renewable energy manufacturers that do not pay attention to women's needs will be missing a huge potential market. Energy policymakers who ignore women's needs will be failing to make use of a powerful force for renewable energy development. Energy researchers who leave women out of energy research and analysis will be failing to understand a large part of energy consumption and production. Donors who do not support gender-sensitive energy assistance will be overlooking one of their primary target groups.

Much work remains to be done. For example, an economic framework for including human energy and health externalities would greatly facilitate including women's activities in the energy sector. More detailed case studies of the results of including or not including women in renewable energy projects would be of enormous use in convincing policymakers and practitioners, as well as in training. The disaggregation of data by gender should be standard practice in all renewable projects offering immediate insights to those directly involved in implementation, and also in monitoring of impacts and benefits.

Nonetheless, the main conclusions necessary for action are clear, as stated in the report of the World Renewable Energy Congress-V in Box 5.

A growing group of women and men, ranging from grassroots women and extensionists to researchers to policymakers and donors, believe that gender is important enough to warrant special attention in renewable energy. At the same time they know that a gender perspective represents but one piece of the complex equation that can lead to successful renewable energy projects and enterprises - not a sufficient piece alone to assure success, but a necessary piece for success.

${ }^{6}$ ENERGIA, c/o ETC International, P.O. Box 64, 3830 AB Leusden, The Netherlands, www.energia.org. 
Box 5

Findings on Gender and Energy, World Renewable Energy Congress - V, 21-25 September, 1998, Florence, Italy

(1) Women are the group most affected by energy scarcity and related environmental degradation, economically, in time spent on subsistence activities, and in negative health impacts.

(2) Renewables hold great potential for improved quality of life for women because they ease the time and human energy needed to meet daily needs, while helping to improve indoor air quality.

(3) Women's role in energy is so important that we need women to be involved in energy decision making. Renewables must be applied in a culturally sensitive manner, and in such a way to actually meet women's needs.

(4) The opportunity now exists to mainstream gender in sustainable energy development. Gender and sustainable energy is emerging as a credible field. Clearly, much better empirical data is needed on gender and renewable energy.

Finally, it was recommended that an international assessment of the state of knowledge on gender and energy, in which researchers and practitioners come together to identify what is known, and what needs to be discovered, is undertaken to move this important area forward.

Source: Farhar 1998b. 


\section{References}

Agarwal, Bina. 1986. Cold Hearths and Barren Slopes: The Woodfuel Crisis in the Third World, London: Zed Books, 209 pp.

Alcantara, Elsa, et al. 1986. Crisis de Energia Rural y Trabajo Feminino en Tres Areas Ecologicas de Peru, World Employment Programme Working Paper No. 38 (International Labor Organisation, Geneva), 117 pp.

Appleton, Helen, Maria E. Fernandez, Catherine L.M. Hill, and Consuelo Quiroz. 1995a. "Claiming and Using Indigenous Knowledge," pp. 55-71 in United Nations Commission on Science and Technology Development, Gender Working Group, Missing Links: Gender Equity in Science and Technology for Development, IDRC (Ottawa, a), 376 pp.

Appleton, Helen. 1995b. Do It Herself: Women and Technological Innovation, London: IT Publications, $256 \mathrm{pp}$.

Ardayfio, Elizabeth. 1986. The Rural Energy Crisis in Ghana: Its Implications for Women's Work and Household Survival, World Employment Programme Working Paper No. 38. Geneva: International Labor Organisation, 104 pp.

Banks, Leslie, Bongani Mlomo and Phumeza Lujabe. 1996. Social Determinants of Energy Use in LowIncome Households in Metropolitan Areas (Eastern Cape), Johannesburg, South Africa report to the Department of Minerals \& Energy, October, 147 pp.

Barnes, Douglas F., Keith Openshaw, Kirk Smith, and Robert van der Plas. 1994. What Makes People Cook with Improved Stoves? A Comparative International Review of Stove Programs, Technical Paper No. 242, Energy Series, Washington, DC: The World Bank, 29 pp.+app.

Barua, Dipal. 1998. "Energy's Role in Rural Income Generation: The Grameen Strategy.” Paper presented at Village Power '98: Scaling Up Electricity Access for Sustainable Rural Development, NREL/World Bank, Washington, DC, October 6-8, 9 pp.

Bassani, Antonella. 1988. "The Informal Sector: Opportunities and Future Directions in Urban Energy," ESMAP Household Energy Unit, The World Bank, Washington, DC, 36 pp.

Biomass Energy Services and Technology (BEST). 1988. The Use of Wood Fuels in Rural Industries in Asia and Pacific Region, Bangkok: Regional Wood Energy Development Programme in Asia/Food and Agriculture Organisation (RWEDP/FAO).

Boserup, Esther. 1970. Women's Role in Economic Development, New York: St. Martin's Press.

Brouwer, I.D., et al. 1989. "Nutritional Impacts of An Increasing Fuelwood Shortage in Rural Households in Developing Countries," Progress in Food and Nutrition Science 13.

Bryceson, Deborah Fahy and Michael K. McCall. 1997. "Lightening the Load on Rural Women: How Appropriate is the Technology Directed Towards Africa?" Gender, Technology and Development 1 (1) pp. 23-45. 
Carr, Marilyn. 1984, Blacksmith, Baker, Roofing-sheet Maker . . Employment for Rural Women in Developing Countries, London: IT Publications, 144 pp.

Cecelski, Elizabeth. 1996. Decentralized Rural Electrification for Sustainable Development, Working Paper No. 77, University of Twente, Technology and Development Group, Enschede, The Netherlands.

Cecelski, Elizabeth. 1992. "Energy and Rural Women's Work: Crisis, Response and Policy Alternatives," International Labor Review 126 (1) 41-64.

Cecelski, Elizabeth. 1993. "Energy and Women in Developing Countries: Trends and Policy Issues," Paper presented to the UNIFEM Expert Group Meeting on Science \& Technology and the UN Commission on Science \& Technology for Development, Working Group on Gender, 14-18 December, New York. 10 pp.

Cecelski, Elizabeth. 1983. "Findings of Mission to Pakistan, Islamabad and Peshawar, Nov. 28 - Dec. 5, 1983," photocopy (ILO, Geneva), 6 pp.

Cecelski, Elizabeth. 1995. "From Rio to Beijing: Engendering the Energy Debate," Energy Policy 23:561-575.

Cecelski, Elizabeth. 1996. "Gender \& Energy: Past, present, future," Background paper for Brainstorming and Planning Meeting on ENERGIA: Women and Energy Network, 4-5 June, University of Twente, Enschede, The Netherlands.

Cecelski, Elizabeth. 1989. "Women's Involvement in ESMAP Activities: A Review of Past Experience and Implications for a Future Strategy on Energy and Women," Report to ESMAP, March, 37 pp.

Clancy, Joy. 1999. Personal communication.

Clancy, Joy. 1998. "Meeting ENERGIA Members: Priyanthi Fernando," ENERGIA News, vol 2 no 2 (p. 7).

Dauber, R. and Cain, M. (eds) 1981. Women and Technological Change in Developing Countries, Boulder: Westview Press.

Doraswami, Anand. 1994. "Solar Water Heating Systems in India," Energy for Sustainable Development 1(1), pp. 51-57.

Dutta, Soma, Ibrahim H., Rehman, Preeti Malhotra, and Venkata Ramana P. 1997. Biogas: The Indian NGO Experience, AFPRO-CHF Network Programme, New Delhi: Tata Energy Research Institute, $128 \mathrm{pp}$.

Dutta, Soma, 1997. "Role of Women in Rural Energy Programmes: Issues, Problems and Opportunities," ENERGIA News, vol 1 no 4, pp. 11-14.

ENERGIA, 1998. Meeting Report and Documentation, Second Annual meeting of the ENERGIA Support Group, Amsterdam, 25-26 September 1997, Amsterdam: ENERGIA, International Network on Women and Sustainable Energy, January. 
Everts, Saskia. 1998. Gender \& Technology: Empowering Women, Engendering Development, London: Zed Books, 171 pp.

Everts, Saskia and Bob Schulte. 1997. "Vietnam Women's Union Promotes Solar Energy," ENERGIA News, vol. 1 no. 3 (p. 12-13).

Food and Agriculture Organisation/Forests, Trees and People Programme (FAO/FTTP). 1995. Gender Analysis and Forestry: Training Package, Rome: FAO/FTTP, 9 manuals.

FAO. 1987. Restoring the Balance: Women \& Forestry, Rome: Food and Agriculture Organisation (FAO), $32 \mathrm{pp}$.

Farhar, Barbara C. 1997. Personal communication.

Farhar, Barbara C. 1998a. "Gender and Renewable Energy: Policy, Analysis, and Market Implications," Renewable Energy 15 (1998) 230-239.

Farhar, Barbara C. 1998b. "Report on Women's Activities at the World Renewable Energy Congress V," WREN NEWS, Winter 1998, pp. 1-2.

Fortmann, Louise and Dianne Rocheleau. 1985. "Women and Agroforestry: Four Myths and Three Case Studies," Agroforestry Systems 2:253-272.

Habermehl, H. 1994. "Micro- and Macroeconomic Benefits of Fuelwood Saving Stoves in Burkina Faso, Mail and Niger," GTZ/HEP Eschborn.

Hannah-Andersson, Carolyn. 1984. Development of Water Supplies in Singida Region, Tanzania: The Realities for Village Women, Research Report No. 63, Institute of Resource Assessment, University of Dar es Salaam.

HEP. 1993. Household Energy Supply, Examples of Projects Supported by the German Technical Cooperation (GTZ), No. 2. 93, Eschborn: Gesellschaft für Technische Zusammenarbeit (GTZ), $28 \mathrm{pp}$.

Hooper-Box, Caroline, Khibi Mabuse, and Wrenelle Ruiters. A Conceptual Review and Reassessment of South African Energy Policy Research Methodology: Towards an Expanded Framework for Gender and Energy Research, Johannesburg: Department of Minerals and Energy, March, 54 pp.

Hosier, Richard. 1994. Informal Sector Energy Use in Tanzania: Efficiency and Employment Potential, Energy, Environment and Development Series - No. 25, Stockholm Environment Institute, 12 pp.

Ilkaracan, Ipek and Helen Appleton. 1994. Women's Roles in the Innovation of Food Cycle Technologies, New York United Nations Development Fund for Women (UNIFEM) with the Intermediate Technology Development Group (ITDG) 90 pp.

Intermediate Technology Development Group (ITDG). 1998. "International Programmes: Focus on Intermediate Technology Group (ITDG) Energy Programme," ENERGIA News, vol 2. no. 2 (pp. 4-5). 
Intermediate Technology Group. 1992. "Women, Woodfuel, Work \& Welfare," Special Issue No. 27 of Boiling Point, Rugby, UK: Intermediate Technology Development Group (ITDG). 39 pp.

International Labor Organisation (ILO). 1987. Linking Energy with Survival: Energy, Environment \& Rural Women's Work, Geneva: International Labour Organisation (ILO), 32 pp.

Jones, Sean, Robert Aitken, and Leanne Luckin. 1996. An Ethnographic Study of the Social Determinants of Fuel Use in Cato Manor, Durban, Report to the Department of Mineral \& Energy Affairs, Johannesburg, South Africa, February, 203 pp.+app.

Kelkar, Govind. 1981. "Gobar Gas: Showpiece of Sadiquura,” Economic \& Political Weekly, XVI (9), Bombay, India, February.

Kennedy, Ellen B. and Rosana Rodrigues dos Santos. 1998. "International Programmes: Focus on Winrock International,” ENERGIA News, vol. 2 no. 1 (pp. 7-9).

Kumar, Shubh K. and David Hotchkiss. 1988. Consequences of Deforestation for Women's Time Allocation, Agricultural Production, and Nutrition in Hill Areas of Nepal, Washington, DC: International Food Policy Research Institute (IFPRI), 72 pp.

Mehlwana, Anthony and Nomawethu Qase. 1996. Social Determinants of Energy Use in Low-Income Metropolitan Households in the Western Cape (Phase 1), Report to the Department of Mineral \& Energy Affairs, Johannesburg, South Africa, May, 66 pp.+app.

Murphy, Josette. 1997. Mainstreaming Gender in World Bank Lending: An Update, A World Bank Operations Evaluation Study, Washington, DC: The World Bank, 64 pp.

Narayan-Parker, Deepa. 1988. Kenya: People, Pumps and Agencies, A Case Study, PROWWESS/UNDP Involving Women in Water and Sanitation: Lessons - Strategies - Tools, New York: United Nations Development Program, 39 pp.

Nathan, Dev. 1997. "Economic Factors in the Adoption of Improved Stoves," Wood Energy News vol. 12 no. 1 (pp. 16-18) (December 1996/April 1997).

Obaid, Thoraya A. and Mahmoud A. Saleh. 1997. "Diffusion of Biogas Technology: The Development of Women in Al-Habeel Village," ENERGIA News vol. 1 no. 3 (pp. 8-10).

Okalebo, Jane and Mark Hankins. 1997. "Why Women Adopt Solar Dryers," ENERGIA News vol. 1 no. 3 (pp. 6-7).

Oliveiros D., Alfredo. 1998. "Energising' Rural Areas of Peru," ENERGIA News vol. 2 no. 1 (pp. 14-15).

Palmer Development Group. 1997a. Gender Review of the GTZ/DME Solar Cooker Field Test, Report to Gesellschaft für Technische Zusammenarbeit (GTZ), Eschborn, November, 32 pp.+app.

Palmer Development Group. 1997b. End-User Acceptance, Solar Cooker Field Test in South Africa, Phase 1; Main Report, Volume 1, Johannesburg: PDG/GTZ, November, 75 pp.

Pandey, M.R. et al. 1995. "Indoor Air Pollution in Developing Countries and Acute Respiratory Infections in Children," The Lancet, 1989, pp. 427-429, in UN. 
Peskin, Henry M., Willem Floor and Douglas F. Barnes. 1992. Accounting for Traditional Fuel Production: The Household Energy Sector and Its Implications for the Development Process, Industry and Energy Department, Washington, DC: The World Bank.

Putti, Venkata Ramana. 1998. As If Institutions Matter: An Assessment of Renewable Energy Technologies in Rural India, PhD dissertation, Technology and Development Group, Enschede, The Netherlands; University of Twente, 238 pp.

Reddy, Amulya. 1996. "Energy for Women and Women for Energy: Empowering Women Through Energy Entrepreneurship," ENERGIA News, vol. 1 no. 1 (pp. 11-13).

Skutsch, Margaret. 1997. Gender in Energy Training Pack, Enschede, The Netherlands: Technology and Development Group, Enschede: University of Twente, Occasional Paper No. 9 ( June), modular manual.

Skutsch, Margaret. 1995. Gender in Energy: How Some Major Donors See It, WP No. 71, Technology \& Development Group, Enschede: The Netherlands, University of Twente, 35 pp.

Sloman, Lynn. 1993. "Putting Women in the Picture: Participation in Transport Policy-Making," in VeloCity Report, VIIth VeloCity Conference, Nottingham, pp. 537-540.

Smith, Kirk R. 1993. "Fuel Combustion: Air Pollution Exposures and Health in Developing Countries," Annual Review of Energy and Environment (18).

Sow, Fatou. 1986. Les Femmes et Les Projets D'energie Au Senegal: Impact sur le Travail Feminim et le Bien-etre Familial, World Employment Programme Technical Cooperation Report, Geneva: International Labour Organisation (ILO).

Spitzner, Meike. 1993. "Approaches to Reducing Road Traffic Volumes," Contribution to the First Session of the Wuppertal International Advisory Council, Wuppertal, Germany: Wuppertal Institute for Climate, Environment and Energy, June 14-15, 12 pp.

Stone, Laurie. 1998. "Solar Baking Under the Sonoran Sun," ENERGIA News, vol. 2 no. 1 (pp. 12-13).

The Economist. 1993. "Horror in the Woods," October 23, p. 62.

Tinker, Irene. 1990. "The Real Rural Energy Crisis: Women's Time," pp. 5-40 in Ashok Desai (ed), Human Energy, New Delhi: Wiley.

Torres, Stella Maria. 1998. "Women as Professionals in Energy in Latin America: How Many?" ENERGIA News, vol. 2 no. 1 (pp. 16-17).

United Nations. 1995.The World's Women 1995: Trends and Statistics, New York: UN, 188 pp.

UNDP. 1997. Energy After Rio: Prospects and Challenges, New York: UNDP, 176 pp.

UNDP. 1995. Human Development Report 1995, New York: UN, 230 pp. 
UNIFEM with ITDG. 1988. Cereal Processing, Food Cycle Technology Sourcebook \#3, New York: UNIFEM, $69 \mathrm{pp}$.

UNIFEM with ITDG. 1993. Drying, Food Cycle Technology Sourcebook \#6, New York: UNIFEM, $62 \mathrm{pp}$.

UNIFEM with ITDG. 1988. Fish Processing, Food Cycle Technology Sourcebook \#4, New York: UNIFEM, 91 pp.

UNIFEM with ITDG. 1989. Root Crop Processing, Food Cycle Technology Sourcebook \#5, New York: UNIFEM, 74 pp.

van der Plas, Robert Jan. 1994. "Solar Energy: A Neglected Answer to Rural Power in Africa," Energy for Sustainable Development 1 (2) (pp. 45-47).

van Wijk-Sijbesma, Christine. 1998. Gender in Water Resources Management, Water Supply and Sanitation: Roles and Realities Revisited. The Hague: The Hague International Water \& Sanitation Centre, 200 pp.

Wakeman, Wendy. 1995. Gender Issues Sourcebook for Water and Sanitation Projects, UNDP-World Bank Water and Sanitation Program/PROWWESS on behalf of the Working Group on Gender Issues of the Water and Sanitation Collaborative Council, Washington, DC: The World Bank, $125 \mathrm{pp}$.

Wides, Laura. 1998. "Gender Lessons from Community-Based PV Projects in Rural Guatemalan Villages," ENERGIA News, vol. 2 no. 1 (p. 9).

Wonfor, Cheri. 1998. "Improving Public Transport In A South African Urban Community: Gender, Energy And Environmental Perspective On The Taxi Industry," ENERGIA News, vol. 2 no. 3 (pp. 5-7).

Yturregui, Lourdes Palao. 1998. "Coping with a Lack of Electricity in Marginal Urban Areas," ENERGIA News, vol. 2 no. 1 (pp. 18-22). 


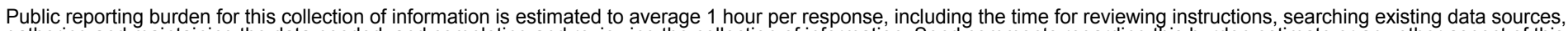

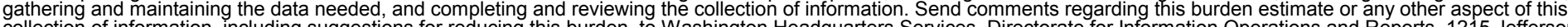
Davis Highway, Suite 1204, Arlington, VA 22202-4302, and to the Office of Management and Budget, Paperwork Reduction Project (0704-0188), Washington, DC 20503.
1. AGENCY USE ONLY (Leave blank)
2. REPORT DATE
3. REPORT TYPE AND DATES COVERED June 2000 Subcontract Report

4. TITLE AND SUBTITLE

The Role of Women in Sustainable Energy Development

5. FUNDING NUMBERS

6. AUTHOR(S)

Elizabeth Cecelski

7. PERFORMING ORGANIZATION NAME(S) AND ADDRESS(ES)

Prepared under Consultant Agreement No.

CXL-7-17475-01

Energy, Environment \& Development Germany

8. PERFORMING ORGANIZATION REPORT NUMBER

9. SPONSORING/MONITORING AGENCY NAME(S) AND ADDRESS(ES) National Renewable Energy Laboratory 1617 Cole Blvd. Golden, CO 80401-3393

10. SPONSORING/MONITORING AGENCY REPORT NUMBER

SR-550-26889

11. SUPPLEMENTARY NOTES

NREL Technical Monitor: Barbara Farhar

12a. DISTRIBUTION/AVAILABILITY STATEMENT National Technical Information Service 12b. DISTRIBUTION CODE

U.S. Department of Commerce

5285 Port Royal Road

Springfield, VA 22161

13. ABSTRACT (Maximum 200 words)

This paper explores the question of how sustainable energy development-specifically, decentralized renewable energy technologiescan complement and benefit from the goal of increasing women's role in development. It is based on a paper that was originally presented at the World Renewable Energy Congress-V held in Florence, Italy, in September 1998, as a contribution to the National Renewable Energy Laboratory's program on gender and energy.

14. SUBJECT TERMS

Women and renewable energy; sustainable energy development; gender perspective in the energy sector

15. NUMBER OF PAGES

16. PRICE CODE

17. SECURITY CLASSIFICATION OF REPORT Unclassified
18. SECURITY CLASSIFICATION OF THIS PAGE Unclassified
19. SECURITY CLASSIFICATION OF ABSTRACT Unclassified
20. LIMITATION OF ABSTRACT

UL 